\title{
İnanç, Mimarlık ve Algı Üzerine Mülahazalar
}

\author{
Muzaffer YILMAZ
}

\begin{abstract}
İnanç, Mimarlık ve Algı Üzerine Mülahazalar
Özet

İster mitler ister dinler aracılığıyla olsun, inanç, tarih boyunca sanat vasıtasıyla kendi algısını yaratmak istemiş, bunu yaparken de muhatabında kalıı bir etki bırakmak için dolaylı (simgesel) bir anlatım tarzını kullanmıştır. İçerisinde kutsalın izlerini taşıyan her mimari eser, imgeden nesneye dönüşme sürecinde kolektif bir algının ürünü olarak ortaya çıkmış ve kendi çağının dünya görüşünün tezahürü olmuştur. Makalede; mimari özelinde, bir sanat eserinin imgeden nesneye dönüşme süreci ve kutsal kavramının mimari ile olan ilişkisi, doğu-batı eksenli olarak ele alınmış, bununla birlikte metinde kronolojik bir sıra takip edilmemiş ve metin, savunulan düşünceler odaklı bir seyir izlemiştir. Makalede ayrıca, geçmişin düşünce ve muhayyile gücünden yoksun olan günümüz İslam Dünyası'nın mimarì faaliyetleri, koruma anlayışı ve yorumlama problemleri, konu dâhilinde irdelenmeye çalışılmıştır.
\end{abstract}

Anahtar Kelimeler: İnanç, Mitoloji, Mimari, Göstergebilim, Algı
Thoughts on Faith, Architecture and Perception

Abstract

Belief wanted to create its own perception over myths or religion by using art throughout history. While it was doing that, it employed a symbolic (indirect) way to imress its answerer. Every architectural work that carries trace of divine, emerged as a product of a collective perception during its process from image to object, and it became an appearance of its own age's world-view. In this article, a work of art's transformation process from image to object in architectural perspective, and the relationship between holy concept and architecture were studied. It was approached in east-west axes. However a chronological order wasn't followed in the text, and it was focused the ideas that are defended. Besides that today's Islam World's architectural activities that are deprived of idea and imagination of past, its protection concept and interpretation problems were examined in matter of subject.

Key Words: Belief, Religion, Mythology, Architecture, Semiotics, Perception

\section{Giriş}

İnanç, Mimarlık ve Algı Üzerine Mülahazalar adını taşıyan makalede; düşünce-muhayyile ile başlayan ve sanat eserinin meydana gelişi ile sonuçlanan süreç, kendi belirleyicileri ile ele alınacaktır. Bu belirleyiciler; 'imge', 'simge', 'sembol' ve 'nesne' kavramları ile ifade edilmekte olup 'muhayyile'nin bu kavramlar üzerinden izlediği seyir ve nihayetinde oluşan 'sanat eseri' özelinde bir değerlendirme yapılacaktır. Ayrıca bu sürece -dinler ve mitler özelinde- inancın etkisi, 'etkileyen' (yani din, ruhban sınıfı, iktidar, erk, devlet) ve 'etkilenen' (yani inanan, mümin, halk, toplum) merkezli olarak ele alınarak irdelenecektir.

Bugünkü insan türünün atası olan Homo Sapiens, yaklaşık 150.000 yıl önce Doğu Afrika'ya yerleşmiş, MÖ 70.000'lerde ise diğer insan türlerini ortadan kaldırmıştır (Harari, 2015: 26,27). Bu-

*Muzaffer YILMAZ, Yrd.Doç.Dr., Necmettin Erbakan Üniversitesi, Geleneksel Türk Sanatları Bölümü, emuzafferyilmaz @gmail.com 
gün genel olarak insan dediğimiz bu tür, varoluşu itibariyle diğer canlılardan ayrılır. Evrende her şey belli bir varoluş prensibiyle yer alır. Örneğin bir hipopotam, hipopotam olarak var olduğu evrenden yine hipopotam olarak ayrılır. Bir ağaç, araba, bardak hakeza. Bu oluşum meselesi, 'şey'in, geliş şekliyle doğrudan alakalı ve sınırlıdır, insan dışında. İnsan olarak var olan canlının akıbeti ise kendi elindedir ve bu durum onu diğer canlılardan ayırmaktadır ${ }^{1}$.

Bu farklılığa neden olan davranışlar, tarih boyunca psikoloji bilimi içerisinde ele alınarak incelenmişti ${ }^{2}$. Bu bilim dalı içerisinde insan davranışları konusundaki kuramlarıyla dikkat çeken üç bilim insanı olmakla birlikte bunlar; Sigmund Freud, Alfred Adler ve Gustave Jung'tur. İnsan davranışlarının psikolojik olarak kökenlerine inerek bu eylemlerin gerekçelerini anlamaya çalışan bu bilim insanlarından Adler'e göre insan davranışlarının temelinde aşağılık duygusu vardır (Adler, 2002: 59,60). Bir diğer bilim insanı Jung'a göre insan davranışlarının temelinde, türe bağlı arketipsel yaşama içgüdüsü yatmaktadır (Jung, 1997: 46,47). Psikanaliz'in kurucusu Freud'a göre ise korunmasaldırganlık ile cinsellik insan davranışlarını belirleyen temel değerlerdir (Freud, 1994: 129,130).

Temelinde ne olursa olsun, insan davranışlarını belirleyen bu düşünme faaliyeti ve bu faaliyetin beraberinde getirdikleri, hem insanı diğer canlı türlerinden ayırmakta hem de onun kendine özgü faaliyetleri ortaya koymasına sebep olmaktadır.

\section{2. İmge, Simge, Nesne İlişkisi}

İmge en genel anlamıyla zihinde tasarlanan şey, hayal ile tanımlanmaktadır (TDK, 2011: 1182). Bununla birlikte imge, düşünülen şey nispetinde, bir yaratılış sürecinin başlangıcıdır. Örneğin Antik Yunan dünyasındaki eğlence kavramı, pek çok parametre ve belirleyicinin devreye girmesiyle (doğa, bahar, dans, müzik vs.) yüzlerce yıllık birikimin ardından insan zihninde, yeniden doğuş ve yenilenmeye bağlı bir eğlence imgesi oluşturmuştur. İnsan aklı daha sonra bu imgeye 'kutsalık' vererek onu somutlaştırmak istediği zaman ise ortaya Dionysos denilen ve eğlence üst başlığı altına girecek pek çok değeri temsil edecek olan bir simge ${ }^{3}$ çıkmıştır ${ }^{4}$. Bu zaruri bir sonuçtur. Çünkü simge, duyu-

\footnotetext{
${ }^{1}$ Bu kendi elindelik, tür içerisindeki pozisyonla alakalı bir durum olup kültür kavramı ile de doğrudan ilişkilidir. Sınıfsal farklııklar, dâhil olunan meslek grupları, statüler, unvanlar vs. hep bu çerçeve içerisinde değerlendirilebilir. Bu durum daha geniş manada bir ihtiyaç-tüketim ilişkisi dâhilinde de ele alınarak incelenebilir. Ayrıntılı bilgi için bkz. Cengiz Yanıklar, "Tüketim Kültürü, Kapitalizm ve İnsan İhtiyaçları Arasındaki İlişki Üzerine Bir Tartışma", Cumhuriyet Üniversitesi Sosyal Bilimler Dergisi, C:34, S:1, Sivas, 2010, s.25-32; Tüketim kültürü ve sanat ilişkisi üzerine farklı bir çalışma için bkz. Mehmet Susuz, "Tüketim Kültürünün Sanata Yansıması", Inönü Üniversitesi Sanat ve Tasarım Dergisi, S:6, Malatya, 2016, s.200-211.

${ }^{2}$ Farklı bilim insanlarının onu hakkındaki görüşlerini içeren bütüncül bir derleme için bkz. Orhan Hançerlioğlu, Felsefe Ansiklopedisi, Remzi, İstanbul, 1985.

${ }^{3}$ Kavramların kendisi dahi simgeler üzerine kurulmuş bir dünya olup simgeler; arka planında toplumsal eylemlerin oluşturduğu (bahsedilen örnekte olduğu gibi), soyut-somut, herhangi bir şeyin yerini tutan ifadelerdir (Aydın, 2017: 35). Bu açıdan bakıldığında simgeleri, işaretler ve semboller olarak ikiye ayırmak mümkün olmakla birlikte işaret, görünce herkesin anladığı (örneğin bir trafik işareti); sembol ise anlamı bir toplum ve belirli bir sosyo-kültürel seviyeye
} 
lar ve hayal gücü ile yapılamayacak olan somutlaştırmanın biricik koşuludur ${ }^{5}$. Bu süreçte inancın ${ }^{6}$ (yani kutsalın) etkisini yadsımak mümkün olmamakla birlikte, mitlerin ortaya çıkış gerekçelerinden birinin bu somutlaştırma süreci olduğunu söylemek dahi mümkündür. Bu konuda M. Bilgin Saydam şunları söyler: lç gerçekliğin içerik ve dinamikleri bilinçli bir anlama ve kavrama çabalarına rağmen kendilerini bütünüyle belli etmezler. Mitler bu iç dinamiklerin dış gerçekliğe yansıtılmasına, yani soyutun somutlaştırılmasına olanak sağlarlar (Saydam, 2017: 49,50).

İmge'den simgeye giden bu sürecin, sonrasında kendine nesnel bir karşılık bulması ise mimari ile olmuştur. Tanrı Dionysos adına yapılan ve dini bir ritüel geçit törenleri, oyunlar ve canlandırmalar; dram, komedi ve trajedinin doğmasına, böylelikle de tiyatronun temelinin atılmasına yol açmış$\operatorname{tır}$ (Grimal, 2012: 155). Buradan hareketle tiyatrolar antik dünyanın birer eğlence mekânları olmalarının yanında, aynı zamanda tanrı Dionysos ile irtibatlandırılan kutsal yapılardır (Çizim 1). Bir sanat eserinin meydana gelme sadedinde, ciddi bir alglama ve tümden gelim sürecini takip etmek mümkündür (Fotoğraf 1, 2). Burada görüldüğü üzere düşünme ve muhayyile ile başlayan süreç önce imgeyi (eğlence), daha sonra simgeyi (Dionysos), nihayetinde ise nesneyi (tiyatro) meydana getirerek tamamlanmıştır?

İmgeden nesneye giden bu sürecin en önemli belirleyicisi ise 'ide'dir. 19. yüzyılın en önemli filozoflarından olan Immanuel Kant ideyi tin (maneviyat) ile ilişkilendirmekte ve hiçbir belirlenimli düşüncenin, yani hiçbir kavramın kendisine karşılık gelmediği, fakat daha fazla düşünceye yol açan, hayal gücünün bir tasarımı şeklinde yorumlamaktadır (Kant, 2007: 207). Kant'ın tespitinden de anlaşılacağı üzere ide, aslında bir sanat eserinin, olması gereken nispetinde olmasına neden olacak olan değerdir ${ }^{8}$. Bir antik dönem tanrı heykelinin kaslı (ideal) yapılma gerekçesi dahi, bu ide ile ilişki-

sahip kişiler tarafından anlaşılabilecek (örneğin bir hilal tasviri) daha karmaşık ifadelerdir. Ayrıntılı bilgi için bkz. Mustafa Aydın, Sembolden İşaretsele Düşüncenin Dönüşümü, Sosyoloji Divanı, C:8, Konya, 2017, s.31-41.

${ }^{4}$ Dionysos; Roma Mitolojisi'ndeki Baküs (Baccus). Yunan Mitolojisi'ndeki ikinci kuşak tanrılardan olan Dionysos, Zeus ile Semelen'in oğlu olup doğa, şarap, sarhoşluk ve eğlencenin tanrısıdır. Ayrıntılı bilgi için bkz. Azra Erat, Mitoloji Sözlüğü, Remzi, İstanbul, 2006, s. 91-97. Dionysos kültünün baharın gelişini müjdeleyen ritüellerle de ciddi bir ilişkisi bulunmakla birlikte, bu ilişkinin kökenlerini Sümer Mitolojisindeki tanrı Dumuzi'ye (Tammuz) kadar götürmek mümkündür.

${ }^{5}$ Sözlük anlamı olarak simge: duyularla ifade edilemeyen bir şeyi belirten somut işaret, alem, rumuzdur.

${ }^{6}$ Burada inançla kastedilen mitolojidir. Mitoloji konusunda araştırma yapanlar: mitleri ve dinleri aynı kaynağın ürünü olarak görenler ve görmeyenler olarak -temelde- ikiye ayrılmaktadır. Ayrıntılı bilgi için bkz. Fuzuli Bayat, Mitolojiye Giriş, Ötüken, İstanbul, 2017.

${ }^{7}$ Bu durum, mimari dışındaki sanat türleri içinde geçerlidir. Örneğin; Latince korno denilen müzik aletinin kökeni, boynuzdan yapılan eski bir müzik aleti olan horn'a dayanmaktadır (etimolojik bakımdan gerek korno gerekse horn boynuz anlamına gelmektedir). Güçlü ve kutsal kabul edilen bir hayvanın uzvundan ses çıkartmak, kutsal olanla sanat yoluyla ilişki kurmanın farklı bir boyutudur. Boynuz ve güç-iktidar ilişkisi için bkz. Necmettin Ersoy, Semboller ve Yorumlarla Görünenden Görünmeyene, Kam Ajans, İstanbul, 1990, s.313-315.

8 İde kavramı ilk olarak Antik Çağ filozoflarınca ele alınmıştır. Bu kavramı düşüncenin konusu yapan en önemli ilk şahsiyet Planton'dur. Platona göre yoktan yaratılma diye bir hadise olmamakla birlikte, Platon dünyayı asıl ve duyusal dünya olarak ikiye ayırmaktadır. Onun bu ayrımında, asıl dünyadan kastı idealar âlemiyken duyusal dünya ise idealar 
Muzaffer YILMAZ

lidir. İde ile şekillenen bu sürecin en önemli figürü ise kuşkusuz sanatçıdır. Sanatçı bu süreçte zihin ile teknik bir ilişki geliştiren ve zihnin görüp dokunulabilecek bir kalıbını çıkaran kişidir (Focillon, 2015: 85). Yani imgenin sanat eseri denebilecek bir nesneye dönüşmesi, onu yapan kişi ile doğrudan ilintilidir?

\section{Kutsallık, Mimari ve Algı}

Bir mimari yapıdan aldığımız haz, yani onu beğenmemiz ve ondan etkilenmemiz, eseri algılayışımızla alakalıdır (Roth, 2002: 91). Burada algılayışla kast edilen, yapının duyu organlarımızla olan temasına bağlı olarak bizde uyandırdıkları olup, estetiğin konusudur. Bir bilim dalı olarak estetiğin ilgilendiği güzelin objektif nitelikleri içsel ve dışsal olmak üzere ikiye ayrılmaktadır. İçsel nitelikler: ide, tür ya da tipe uygunluk, yetkinlik, canlılık (ifade); dışsal (biçimsel) nitelikler ise oran ve simetri ile harmoni (uyumdur) (Tunalı, 1989: 201-224). İçsel nitelikler daha çok bir nesnenin özüne ve kendi türüne benzemesi-uygun olması ve bağlı bulunduğu özün özelliklerini taşımasıyla alakalı özelliklerdir. Dışsal (biçimsel) nitelikler ise var olan nesnenin boyutları ve görünüşü ile ilgilidir. Orantı, simetri ve harmoni; bir nesnenin kendisini meydana getiren parçaların ve o nesnenin çevresi ile ilişkisinin uyumu olarak adlandırılabilir. Bu yönüyle biçimsel nitelikler bir bakıma güzelin matematiksel tarafını da tanımlamak için kullanılabilir. Güzeli matematik olarak tanımlayanların başında Platon gelmekle birlikte, Platon öncesi Yunanlı filozofların da güzeli matematiksel olarak ele aldığı, hatta Herakleitos'un güzel ile harmoni kelimesini eş anlamlı kullandığı bilinmektedir (Tunalı, 2004: 56).

Estetiğin içsel nitelikleriyle irtibat kurabileceğimiz, sanat nesnesinin imgeden nesneye dönüşümü sürecindeki kutsallık, algılayıcının ${ }^{10}$ sanat nesnesinden etkilenmesinde önemli bir rol üstlenir. Bu durum yapı bazında böyle olduğu gibi; en üst mimarlık ürünü olan kent içinde geçerlidir. Nitekim pek çok kentin kuruluşunun mitolojik bir arka planının olması, algılayanın kentle olan ilişkisinin boyutunu değiştirir. Örneğin Atina Kenti, tanrı Apollon ile tanrıça Athena'nın mücadelesi sonucunda, mücadeleyi kazanan Athena tarafından kurulmuştur. Ya da Sevilla'yı, babasına kızan Herkül, Quadelkivir (Vadi El-Kebir) nehrinin kenarında kurmuştur (Fotoğraf 3). Şehirlerin kuruluşu kadar

âleminin sadece bir yansıması, bir taklididir. Dolayısıyla duyusal dünyanın yansıması olan sanat eseri, sonuç itibariyle taklidin taklidi olacaktır. Yani sanat, duyular dünyasındaki nesnelerin birer kopyası olup mimesisten başka bir şey değildir. Ayrıntılı bilgi için bkz. Esra Yıldız Turan, "Platon'un İdealar Kuramı Ekseninde Mimesis Olarak Sanat", Tarih Okulu Dergisi, Sayı: 22, 2015, s.1-8.

\footnotetext{
${ }^{9}$ Sanatçının yaptığı her 'şey'de, kutsalın peşinde olarak onu -her an- hissedebilmesi gerekmemektedir. Nitekim bir sanat eserindeki kutsalı oluşturan unsurlar, -bazen- yüzlerce yıllık birikimle standartlaşmış normlar (örneğin bir romanesk ya da gotik dönem kilisesinin giriş kapısı) olabilir. Bu gibi durumlarda bu standartlaşmış normlar, kendini gelenek adıyla mimaride hissettirir. Ayrıntılı bilgi için bkz. Titus Burckhardt, Doğuda ve Batıda Kutsal Sanat, İnsan, İstanbul, 2017.
}

${ }^{10}$ Burada algılayıcı: toplum, insan, mümin. 
yıkılışlarında da mitsel arka planları görmek mümkündür. Paris'in Seçimi ${ }^{\text {n1 }}$ ile bir güzellik yarışmasının sonucuna bağı sürecin akabinde büyük bir yıkım geçiren Truva, buna güzel bir örnektir (Fotoğraf 4). Truva Savaşı, simge ve algı ilişkisi açısından farkıı bir örnek olması bakımından ayrıca önemlidir. Zira bugün hâlen içimizde düşman algısının simgesinin Truva Atı imajı olması, mitolojik bir hadisenin değer yargılarımızı ne kadar etkilediğine bir delildir aslında ${ }^{12}$. Her ne kadar Antik Yunan dünyası için, içerisinde şehirlerinde yer aldığı tüm geniş yeryüzünü kutsallaştırmak bir gerek hâlini almış olsa da (Eco, 2013: 65), bir şehri değerli kılmak için ona kutsallık kazandırmak, insanlık tarihinin genelinde görülen bir uygulamadır. Nitekim bugün Anadolu'daki pek çok şehir ismini, öldükten sonra tanrılaştırılan Romalı imparatorlardan almışıı ${ }^{13}$. Yine Anadolu'da ve Akdeniz Havzası'nın geri kalanında, Makedonyalı İskender tarafından kurulan ve adını ondan alan şehirler mevcuttur ${ }^{14}$. Şehirlere bir kutsalıı vermede inancın etkisi İslam Dünyası içinde geçerli bir durumdu. Emevi Sultanı Abdü'I-Melik'in (685-705) Kubbet-üs Sahra'yı, Hacer-i Muallak taşının üzerine inşa ettirmesi bile, bir bakıma aynı algının gereğidir ${ }^{15}$ (Fotoğraf 5).

İnsanoğlunun inanma ile ilgili olan serüveninde göğün yeri özeldir. Gökyüzünün kendisini doğrudan doğruya kutsal olarak kabul etmek için mitlerin ötesinde göğün kendisine bakmak bile yeterlidir. Buna bağlı olarak hemen hemen bütün inanışlarda, evreni yaratan ve ona hayat veren sonsuz bir bilgeliğe sahip göksel varlıkları görmek mümkündür (Eliade, 2014: 61). Binaenaleyh, pek çok arkaik inançta en büyük tanrılar, bir bakıma hep gök ile ilişkilendirilen simgelerdir ${ }^{16}$. Kadim uygarlıklardaki dini mahiyet arz eden yapıların, örneğin uygarlığın başladığı Mezopotamya coğrafyasının tapınak ve gözlemevleri zigguratların, kentlerin merkezindeki en büyük yapılar olması (fonksiyonel

\footnotetext{
${ }^{11}$ Dünyanın ilk güzellik yarışması sonucunda Paris, Hera, Athena ve Afrodit'in katıldığı müsabakada, Afrodit'in vaadine bağı ılarak onu birinci seçmiş, bunun sonunda da kendisine Truvalı Helen aşık edilmiştir. Ayrıntılı bilgi için bkz. Şefik Can, Klasik Yunan Mitolojisi, Ötüken, İstanbul, 2011, s. 114-116. Truva Savaşı için bkz. Homeros Ilyada, (Çev. A. Erat, A. Kadir), Can, İstanbul, 1999.

12 'Truva Atı'nın (nesnenin), tarihsel süreçte insan zihninde oluşan 'içimizdeki düşman' algısının (burada algıyı imgeyle eş anlamlı kullanabiliriz) bir simgesi olarak kullanılması (ve halen kullanılıyor olması), sadece imgeden nesneye değil, nesneden imgeye giden bir sürecin de varlığını göstermektedir.

13 Örneğin Edirne ismi Roma İmparatoru Adrian'dan gelmekte olup şehrin kadim adı Hadrianopolis'dir. Bkz. Pars Tuğlacı, Osmanlı Şehirleri, Milliyet, İstanbul, 1985, s.102.

14 İskenderun (Türkiye) ve İskenderiye (Mısır) bu şehirlere güzel iki örnektir.

${ }^{15}$ Yapı hakkında ayrıntılı bilgi için bkz. Suut Kemal Yetkin, İslam Mimarisi. AÜ illahiyat Fakültesi, Ankara, 1959. s. 26-29; Abdulkadir Dündar, “Kubbetü’s-Sahra”, Vakıf ve Toplum, Sayı: 5, Ankara 2017, s. 54-59.

16 Yunan Mitolojisi'nin en büyük tanrısı göğü temsil eden Zeus'tur (Roma Mitolojisi'nde Jüpiter) (Ayrıntılı bilgi için bkz Şefik Can, Klasik Yunan Mitolojisi, Ötüken, İstanbul, 2011.). Eski İran dinin her şeyi bilen anlamına gelen bilge baş tanrısı Ahura Mazda'da bir gökyüzü tanrısıdır (Ayrıntılı bilgi için bkz. Nimet Yıldırım, Iran Mitolojisi, Pinhan, İstanbul, 2012.) Şamanizm ya da Kamlık İnancı dediğimiz eski Türk inanç sisteminin baş tanrısı (bazı kaynaklarda Ülgen olarak da geçen) Gök Tengri'dir (Ayrıntılı bilgi için bkz. Bahaeddin Ögel, Türk Mitolojisi I-II, TTK, Ankara, 1998.) Benzer diğer örnekler için bkz. Donna Rosenberg, Dünya Mitolojisi, İmge, İstanbul, 2000.
} 
ve nesnel gerçeklikleri ve yapılış nedenlerinin dışında ve ötesinde), bir göğe yaklaşma ve inandıkları kuvve ile bir irtibat kurabilme arzusunun gereğidir. Bu sebepten ötürü Mezopotamya'da tapınak mimarisinin tarihi, sur ve saray mimarisinden çok daha eskidir (Müller, 2012: 79). Mezopotamya'ya komşu olan Mısır Uygarlığı'nda da benzer bir algı ürününü görmek mümkündür. Piramitlere Mısır dilinde yukarı çıkma anlamına gelen $\mathrm{m}(\mathrm{e}) \mathrm{r}$ denilmekteydi ve firavunlar bu devasa mezar yapılarında aslında güneş tanrısı Ra'yı selamlamaktaydılar (Roth, 2002: 241). Gökyüzü ile ilintili bu anlayış, insanoğlunun gökteki tanrılara inanmamaya başladığı zamanlarda bile değişmemiştir. Ortaçağ Avrupa'sındaki katedrallerin şehrin merkezine inşa edilmesi bile benzer bir algı yönetiminin gereği olup sadece yüce bir yapı inşa edilmesi ile alakalı bir inisiyatif değildi. Ortaçağ insanı, her şeyde tanrıya ilişkin bir bağlantı arayan sezgisel gerçekler ve betimlemelerle dolu bir dünyada yaşıyordu (Eco, 2016: 96). 13. yüzyllın önemli yazar ve düşünürü Dante, zahirdeki ve görünen anlamlar sadece bir örtüden ibarettir diyerek, aslında bu dönem dünya görüşünü özetliyordu. (Guenon, 2014: 9). Göründüğünün ötesinde anlamlar taşıyan bu dünyada mimaride, yalnızca fonksiyonel kaygılar taşımıyordu. Bir Gotik katedralin büyüklüğü sadece çok fazla inananı içine alabilmesine olanak tanımıyor, aynı zamanda göğe öykünmeye çalışan yüceliği ile hem Tunç Çağı'ndaki geleneği devam ettiriyor, hem de inananların üzerinde bir yücelik etkisi oluşturuyordu. Aslında inanç bir bakıma, mimarinin tüm olanaklarıyla bir algı yönetimine girişiyordu. Ortaçağ katedrallerin dış cephelerinde gördügümüz fantastik yaratıklar bile, aslında benzer bir amaca hizmet ederek alegorik bir mesaj veriyordu: kötülükler kilisenin dışında (Fotoğraf 6).

Insanın duyu organlarına büyük ve yüce olarak hitap eden bir nesnenin, insan algısında tanrıyı çağrıştırması, yüzlerce yıllık tecrübenin sonucunda şekillenmiş bilinçaltı için son derece normal bir durumdur. Rudolf Otto, kutsalın özü olarak tanrı kavramı ile eşdeğer gördüğü Numinous'un sanattaki karşılığının özel olarak mimari, mimarideki karşılığının ise ihtişam olduğunu vurgulamakta ve ihtişamı üç unsurun; sessizlik, karanlık ve boşluk olduğunu söylemektedir (Otto, 2014: 100,103). İngiliz felsefeci Edmund Burke (ö.1797) ise yüce ve yüceliği oluşturan teknikler ile kişi algısı üzerindeki etkisi hakkında şunları söyler: Netice olarak yüce kavramını uyandırmak üzere tasarlanmış bütün yapılar, iki nedenden dolayı epeyce loş ve kasvetli olmalıdır. Ilk olarak, bizzat karanlığın diğer durumlarda tutkular üzerinde ışıtan çok daha fazla etkisi olduğu tecrübeyle sabittir. Ikinci olarak da, bir nesneyi çarpıcı hale getirmek için, onu doğrudan aşina olduğumuz nesnelerden mümkün olduğunca farklı hale getirmemiz gerekir. Bu nedenle, bir binaya girdiğinizde açık havadan daha aydınlığa geçemezsiniz; bir kaç derecelik daha loş bir yere girmek yalnızca önemsiz bir değişiklik sağlanabilir ama geçişi bütünüyle çarpıcı hale getirmek için, mümkün olan en fazla aydınlıktan, mimarinin amaçlarına göre mümkün olan en karanlık duruma geçmeniz gerekir ${ }^{17}$ (Burke, 2008: 85).

\footnotetext{
${ }^{17}$ Işık, İslami açıdan da varoluşun birliği (vahdet'ül vücûd) fikrini ifade etmek isteyen sanatçı için, geometri ve ritim ile beraber kullanılan üçüncü araçtır. Bkz. Titus Burckhardt, İslam Sanatı Dil ve Anlam, (Çev. Turan Koç), Klasik, İstanbul, 2009, s.112.
} 
Bu anlatım ve ifade tarzı Ortaçağın İslam dünyası içinde geçerli bir durumdu. Genel bir ifadeyle İslam mimarisinin temel gayesinin makro kozmosu, mikro kozmosta görme arzusu olduğunu söylemek mümkündür. Olaya bu zaviyeden bakıldığında İslam-evren-mimari üçleminde konunun temel nirengi noktasının insan olduğunu belirtmek gerekir. Hz. Ali'nin şu sözü, mevzuyu somutlaştırmak açısından önemlidir: Sen kendini küçük bir cisim sanırsın ama en büyük âlem sende gizlidir (Kaya, 2011: 190).Tasavvuf ekolüne mensup pek çok âlim ve arifin benzer mahiyette sözleri bulunmaktadır. Mevlana Celaleddin Rumi; Insan tanrının usturlabı (Mevlana Celaleddin Rumi, 1994: 17); Muhyiddin Ibn Arabi ise; Allah'a delil insandır (Demirli, 2014: 109) diyerek bu realiteyi vurgulamışlardır.

Genel olarak İslam Dünyası'nın düşünsel kemalinin bir neticesi olarak tasarlanan ideal şehrin bile insani özellikleri taşıması gerektiği, kâinat nasıl insanda tecelli ediyorsa insanında şehirde tecelli etmesi gerektiği düşünülmektedir. Büyük İslam âlimi Farabi, El Medinet'ül Fazıla adlı eserinde şunları söyler: Erdemli ve mükemmel şehir, bütün organları canlı varlığın hayatını tam kılmak ve bu canlı durumda tutmak için birbirleriyle yardımlaşan tam ve sağlıklı bir bedene benzer... ve bedenin organlarında bulunan tabii kuvvetlere, şehrin kısımlarında bulunan iradi meleke ve istidatlar tekabül eder (Farabi, 2017: 98-100). Bu bağlamda sanat da, küçük âlem olan insanda, yaratıcıya ait olan ve kendinde açığa çıkmış isimlerin yine kendinde tecelli ederek fiiliyata dönüşmesinden ibaret bir hadisedir. Nitekim Hz. Muhammed; baktığımda kendisinde Allah'ı nazar etmediğim hiçbir şey görmedim diyerek aslında bu hakikati ifade etmektedir (Necmeddin-i Daye, 2013: 383,384).

Bu açıdan batı dünyası ile doğu dünyası birbirinden kısmen de olsa ayrılmaktadır. Çünkü kadim Hıristiyanlık sanatında, her 'şey' in tanrıya (hakikate) ulaşması için bir gaye güdülmüşken; doğuda, tanrının (hakikatin) her 'şey' de görünmesi amaçlanmıştır.

Bütünün parçada tecelli etmesi algısı, dolaylı bir anlatım tarzını ortaya koymak zorunda olduğu için ister istemez salt taklitten kaçınmayı zaruri kılmış, bu da genel hatlarıyla İslam Sanatı'na soyut bir mahiyet kazandırmıştır. Yani İslam sanatçısı tabiatı birebir taklit etme (mimesis) yerine, tabiattaki soyut unsurlara yönelerek tevhid ve tenzih hassasiyetine bağlı ürünler ortaya koymuştur (ÇayCl, 2016: 198). Geometrik şekillerinde yüksek derecede soyutlamalar olduğu düşünüldüğünde, İslam Sanatı içerisinde, gerek mimaride gerekse tezyinatta, yoğun bir geometrik repertuarı bu sebepten dolayı görmek mümkündür ${ }^{18}$. Tabi buradaki ana nüans, daha önce vurgulandığı gibi, kullanılan tasarımların sadece fonksiyonel gayesinin olmamasıdır. Hatta süsleme alanında kullanılan-isimlendirilen pek çok şekil(çok sayıda belirleyicinin etkisiyle), mimaride sadece süsleme unsuru olarak kullanılmamıştır (Mülayim, 2010: 109).

Geometri, sanatın özünü teşkil etmekle birlikte, özellikle geometrik sınılamaların olmadığı bir mimariden söz etmek mümkün değildir (Lewock, 1996: 132). İslam dünyasında bir hakikati kavramış biçimi olarak tezahür eden geometri, kendini hem plan-form düzleminde (mimari), hem de

\footnotetext{
18 İslam Sanatında Geometrik Süsleme hakkında ayrıntılı bilgi için bkz. Yıldız Demiriz, İslam Sanatında Geometrik Süsleme, Yorum Sanat, İstanbul, 2001.
} 
süslemede göstermiştir. Fakat burada bir hususa dikkat çekmek gerekir ki, o da İslam kentini oluşturan yapıların ve mimari öğelerin, farklı kültür çevrelerinde farklılıklar göstermesi ve farklı anlatımlar sunmasıdır (Mülayim, 2010: 69). Bu durum, İslam düşüncesinin, muhayyilesinin ve tasavvurunun kemale erme ve bu kemalin sanatta tezahür etme süreci ile alakalı bir hadisedir ${ }^{19}$. Bu noktada klasik Osmanlı Mimarisi, düşünce ve muhayyilenin sanat yoluyla mimaride zuhur etmesi açısından oldukça önemlidir.

Genel olarak mimariyi oluşturan sınırlamalarda belli geometrik formlara uyulmak zorundadır (Lewcock, 1996: 132). Birer geometrik şekil olan daire ve kare, Osmanlı Mimarisi'nin ana karakterini oluşturmaktadır. Platona göre hayat dört temel unsurun; ateş, toprak, hava ve suyun birleşiminden oluşmuştur. Toprağın küp tarafından temsil edildiği, küpün yatay kesitinin ise kare olduğu düşünüldügünde kare, esas itibariyle yeryüzünü simgelemektedir (Çaycı, 2017: 66). Daire (küre) ise göğü, dolayısıyla tanrıyı, tanrının iktidar ve gücünü, yani devleti temsil etmektedir ${ }^{20}$. Hakan'ın gücünün tanrısal olması, Sultan'ın yeryüzünde Hak teâlânın gölgesi (zıllullahi fi'l-arz) olarak adlandırılması bir âlem tasavvurunun sonucudur (Cündioğlu, 2007: 73). Binaanelaeyh, Türk mimarisinin örtü sisteminde kare ve karenin içerisine girmiş daire, sembolik olarak arzın ve semanın yani siyaset ile dinin birlikteliğini vurgulamaktadır (Cündioğlu, 2012: 34-35). Ki bu durum, aslında Osmanlı İmparatorluğu'nun yapısı, dünyayı algılayış ve anlatış biçıminin mimarideki temsilidir (Fotoğraf 7). Bu temsil, esas itibariyle İslam Mimarisi özelinde bir yenilik olmamakla birlikte, İslam dünyasının yabancı olduğu bir uygulama da değildir. Nitekim aynı gerekçelerle yapılmış benzer örnekleri farklı kültürlerde, örneğin 6. yüzyılda İstanbul'da Ayasofya'yı inşa eden Doğu Roma'da, ya da çeşitli Asya kültürlerine ait mimari eserlerde görmek mümkündür (Burckhardt, 2017: 145).

Daire ve kare ilişkisi, İslam Dini'ne göre yeryüzünün ilk yapısı olan Kâbe'de de görülmektedir. Kare planlı basit bir yapı olan Kâbe, etimolojik açıdan küp manasına gelmektedir (Lekesiz, 2016:153 $)^{21}$. Küp merkez fikriyle alakalı bir şekildir: zirve, taban nokta ve dört ara yön. Fakat küp formlu olan Kâbe'nin buna tam olarak uymadığını, ana yönlere yapının duvarlarının değil dört köşesinin baktığını, bununda Arap anlayışında ana yönlerin, evrenin dört köşe direği anlamına gelmesiyle (erkân) alakalı olduğunu söylemek mümkündür (Burchart, 2009: 26). Bununla birlikte Kâbe'nin tavafla olan ilgisi, onun fiziki mekânında kaynaklanan dairesel dönme/tavaf boyutunu da oluşturmakta ve Kabe'nin merkezi teşkil ettiği ortamda onu ziyaret etme eylemi, dairesel aksta gerçekleşmekte ve bu dönüş (tavaf); ebedi döngünün eyleme dönüşmüş şeklini temsil etmektedir (Çaycı, 2017: 63). Dünyanın güneş, güneşin kendi sistemi, Samanyolu galaksisinin ise evrendeki

\footnotetext{
19 İslam Mimarisi'nin tarihi seyri, etkilendikleri kültür çevreleri ve örnekleri için bkz. Oleg Grabar, İslam Sanatı'nın Oluşumu, (Çev. Nuran Yavuz), Kanat, İstanbul, 2010.

${ }^{20}$ Psikoloji bilimi açısından daire; hayatın tek, en can alıcı yönünü, onun nihai bütününü simgeler (Jung, 2016: 236). Bu açıdan bakıldığında da; hayat, teklik, bütünlük ve tanrı arasında bir bağlantı kurulabilmektedir.

${ }^{21}$ Ka'b kökenden gelen Kâbe aynı zamanda yüksek anlamına gelmektedir.
} 
seyri düşünüldüğünde, aslında bu dönüş-tavaf, âlemin bir temsili olarak kabul edilebilir ${ }^{22}$ (Fotoğraf 8).

Bir yapıya bağı ritüelle ilişkili bu âlem tasavvurunu, süsleme örneği üzerinde de görmek mümkündür. Kare bir merkeze bağlı dönüş hareketinin simgelendiği ve çarkıfeleğin ${ }^{23}$ geometrik versiyonu olarak kabul edebileceğimiz svastika (Fotoğraf 9) yapılış prensibi itibariyle âlemi sembolize etmektedir (Guenon, 2014: 74). İslamiyet öncesi dönemlere ait olan fakat farklı tipleriyle İslam, özellikle de Türk-i̇slam devletlerinde çok sık kullanılan bu motif, insan aklının ve algısının bir ürünü olarak belki de kadim insanlığın en büyük soyutlamalarından biridir ${ }^{24}$.

İslami dönem yapıları dışında, yapıları meydana getiren öğeler bazında da, bir dünyayı algılayış biçiminin tezahürü olarak ortaya çıkan simgesel anlatım tarzını görmek mümkündür. Minare ve alem, buna güzel bir örnektir. İslam Mimarisi'nde ilk minare örnekleri Kayravan (726), Harran (750) ve Samarra (852) camilerinde görülmektedir (Bloom, 1989: 31,36,37,61). Üzerinde ezan okunan, yüksek ve kulevari bir mahiyet arz eden minare, ışık anlamına gelen nur kelimesinden türemiş olup, mabedin göğe (bir bakıma güneşe-ışığa) uzanan en yüksek kısımları olan minareler, (kelime anlamını ses ile harmanlayarak),âlemi Ezan-ı Muhammedi ile ışıtmaktaydı (Cündioğlu, 2012: 25). Elif harfi İslamiyet'teki cem makamı olup ona ait olan isim, her şeyi ayakta tutmak olan kayyumluktur (ibn Arabi, 2015: 86). İslam sembolizminde teklif ve birlik makamının sembolü olan elif harfinin adeta mimarideki karşılığı olan minareler, aynı zamanda haşmet ve celal sıfatının da sembolüdürler (Çaycı, 2017: 134,136). Minareler nasıl mabedin göğe en yakın öğeleriyse, minarenin de göğe en yakın uç kısmı alemdir (Fotoğraf 10,11). Alemin uç kısmında yer alan hilâl, İslam sembolizminde Allah'ı temsil etmektedir ${ }^{25}$. Bununla birlikte Sâî Mustafa Çelebi, Mimar Sinan'ın anılarından oluşan Tezkiretü'l Bünyan ve Tezkiretü'l Ebniye adlı eserinde, alemin bizzat $\mathrm{Hz}$. Muhammed'i simgelediğini belirtmektedir (Sai Mustafa Çelebi, 2003: 83). Görüldüğü üzere İslam Mimarisi'nde minare ve alem, ortaya çıkış prensibi itibariyle derin birer algı ürünleri olmaları itibariyle, fonksiyonelliklerinin

\footnotetext{
22 Mimaride kullanılan dikdörtgen plan, karenin bir değişik formu olarak kabul edilebilir. Bu sebepten dolayı dikdörtgenin, kare ile benzer bir sembolik anlam taşıdığını söylemekte mümkündür. Bu açından bakıldığında, Hicr-i İsmail denen alanla beraber düşünüldüğünde Kâbe'nin dikdörtgen bir plana evriliyor olması, metinde vurgulanan kare-dairetavaf ilişkisi bakımından bir problem oluşturmamaktadır.

${ }^{23}$ Türkçede gökyüzünün, göğün, yıldızların (gezegenlerin) çarkı anlamına gelen çarkıfelek, pek çok farklı kültürde motif olarak kullanılmıştır. Genel olarak hareket ve zaman ilişkisini temsil eden çarkıfelek, döngü, deveran, doğum ve ölüm, başlangıç ve son gibi, pek çok ikonolojik anlamı ihtiva etmektedir. Konu ile ilgili bkz. Ahmet Çaycı, "Zaman ve Sanat Bağlamında Çark-ı Felek Motifi", Uluslararası İlam Medeniyetinde Zaman Sempozyumu Bildirileri, (8-11 Ekim 2015), C:2, 2016, s.299-30

${ }^{24}$ Esas itibariyle mabedin (mimari) kendisi de yüksek düzeyde bir soyutlamadır. Sürekli hareket halinde olan evrenin (ilahi gücün), yeryüzündeki hareketsiz sabit bir temsili, sembolüdür. Bu açıdan bakıldığında mabed, zamanın mekâna dönüşümüdür bir bakıma.

${ }^{25}$ Ebced hesabına göre her iki kelimenin de sayı değerleri 66'dır. Ebced Hesabı için ayrıntılı bilgi için bkz. Ramazan Ayçiçek, "Bilgi Değeri Açısından Cefr ve Ebced -Harfler ve Rakamlar Metafiziği-", Milel ve Nihal (İnanç Kültür ve Mitoloji Araştırmaları Dergisi), Yıl: 2, Sayı:1, 2004, s. 75-114.
} 
ötesinde manalar taşımakta ve bir bakıma adeta, yaratıcı ile peygamberinin temsili pozisyonuna gelmiş bulunmaktadırlar.

Yapı ve öğe ile kutsal arasında bu şekilde bir ilişki kurmak, doğu için sadece İslam dünyasına özgü bir gelenek değildir. Örneğin Budizm'de kişinin tanrıyla irtibatında nesne yardımının çok özel bir yeri olmakla birlikte, Stupalar, Budizm'de sadece bir mezar anıtı olarak faaliyet göstermemekte, kendi mümini için dünyanın bir modelini ve Buda'nın bedenini simgelemektedir (Eliade, 2004: 22,23). Kadim Hint öğretisine göre de dünyadaki tüm sanatlara, devaların (ilahi ruh=tanrı) taklit etmek suretiyle ulaşılabilirdi ve doğal olarak mabedin kendisi de, Hint düşüncesine göre ilahi ruhun bir tezahürü ve sembolüydü (Burckhardt, 2017: 11,33).

\section{Değerlendirme ve Sonuç}

Göstergebilim açısından nesne (gösterilen), iki belirleyiciye sahiptir; gösteren (algılatan) ve gösterilen (algılayan). Bununla birlikte her gösterge (nesne) bir simgesel koordinata bağlı eğretilmeli bir derinlik taşır ve yorumlayıcısının (gösterilen) bilgi-kültür düzeyine göre çok farklı anlamlar taşıyabilir ve hatta nesne, kendi öz değerlerimizi yükleyebileceğimiz bir mahiyet bile kazanabilir (Barthes, 2016: 198,203). Sanat eserini de bir nesne olarak kabul ettiğimizde, düşüncemuhayyileden sanat eserine dönüşen ve bir algı yönetimi girişimi olarak değerlendirilebilecek sürecin ürünü olan nesnenin, gösteren ve gösterilen merkezli bir seyir izlediğini söylemek mümkündür. Burada gösteren bir bakıma çağın aklını, kültürel birikimi, somut olarak ise (yerine göre) dinî otorite veya siyasi erk-iktidar diyebileceğimiz grubu; gösterilen ise halkı, inanları (müminleri) temsil etmektedir. Bu açıdan bakıldığında -sanat eserinin özünü oluşturan- her imgeyi, bir görme tarzının somutlanması; her görüş tarzını da, döneminin temsil ettiği temayüllerin ${ }^{26}$ yansıması olarak kabul etmek mümkündür (Leppert, 2009: 20, 23).

Bu noktada önemli olan husus, bu algı yönetimi girişiminde hangi çağda olursa olsun, düşünce ve muhayyilenin salt inancın argümanlarından yararlanılmamıs olmasıdır. Felsefe, fizik, astroloji, biyoloji gibi pek çok farklı disipline bağlı birikimlerin bir neticesi olarak ortaya çıkan düşünce ve muhayyile, inanç adına önce imgeyi meydana getirmiş, daha sonra somut dünyaya (nesneye) nüfuz ederek, yüksek sanat eserlerinin vücuda gelmesine olanak tanımıştır. Bu yüzden her sanat yapıtı, kendisi için ve kendinde oluşmuş (biçimlenmiş) bir yapının biricik ve tek yansımasıizdüşümüdür (Bülbül, 2017: 77).

Bugün ne geçmişteki sanat nesnesini ortaya koyan ne de ondan istifade eden aklın idraki ve dünyayı kavrayış genişliği o seviyede olmadığı için, özellikle İslam Dünyası iki ciddi problemle karşı karşıyadır.

\footnotetext{
${ }^{26}$ Leppert burada temayülü, kültür ile eş anlamlı olarak kullanmıştır.
} 
Bunlardan ilki; sanatı üreten iradenin yetkinliğinin olmaması ve buna bağlı olarak İslam mimarisinin geçmişin kopyası eserler meydana getirmesinden ileriye gidememesidir. Çünkü her sanat eseri genel olarak kendi çağının birikimlerinin, dünya görüşünün ve algılamasının ürünü olarak kendi çağının çocuğu olup, kendine özgüdür (Kandinsky, 2015: 27). Bu yüzden günümüzde, içerisinde döneminin fizik ve astronomi bilgisinin de yer aldığı- ortaçağ dünya görüşünün ürünü olan mimarinin tekrarlarına gitmek, başlı başına bir acizlik ifadesi olup eski çağlara ait tüm bu tekrarlar, o çağa ait yaratıların, en iyi ihtimalle birer kopyası olmaktan öteye gidememektedir ${ }^{27}$ (Fotoğraf 12).

İslam inancını salt ilahiyat merkezli bir zaviyeden yorumlamanın sonucunun İslam mabedine tesiri, mekânların sadece ibadet alanı olarak değerlendirilmesidir. Bu noktada Ahmet Çaycı'nın şu tespiti mühimdir: İslam sanatının anlam dağarcığını besleyen unsurlar arasında felsefe, tasavvuf gibi disiplinlerin dışında, Hermetik, Orfeik, Gnostik gibi yaklaşımlarında olmasından dolayı islami ilimlerin diğer öğretilerle olan bağlantısının ifş̧a edilmesi gerekmektedir (Çaycı, 2017: 54) ${ }^{28}$. Türkİslam mimarisinde II. Ulusal Mimarlık Dönemi'nden sonra özgün bir mimari geleneğin ortaya konamaması da aynı nedenle ilişkilidir ${ }^{29}$; çağın düşüncesini ve algısını yakalayamamanın hazin sonu olarak bir üslup ortaya koyamamak.

İkinci problem ise toplumun mevcut eserleri yorumlayıp değerlendirecek birikime ve algıya sahip olmamasıdır. Burhanettin Tatar'ın İslami bir sanat eserinin mahiyetine ilişkin şu tespitleri dikkat çekicidir: Hiçbir zaman ressamın çizdiği bir resim sadece resim değildir. Yani özne karşısında nesnelleşen ve genel bir perspektiften hareketle yassılaştırılan bir basit varlık imgesi değildir. Aksine her resim ressam ile ressamın muhayyilesine konu olan varlık arasındaki özgür oyun alanı olarak bir sanat eserine dönüşür. Dolayısıyla bir sanat eserini yassılaşan gerçeklik imgesine dönüştüren faktör, tablonun kendisi değil, ancak bu tabloya özne-nesne ikilemi içerisinde yaklaşan gözlemci ya da yorumcudur (Tatar, 2016: 115). Vurgulanan bu husus, kültürel mirası koruma bilincinin kaybolmasına da yol açmaktadır. Zira bir sanat eserini anlamlandırmaktan yoksun bir akıl için koruma kavramı, bir mâna ifade etmemektedir. Tarihi bir cami, çeşme ya da sebille fonksiyonelliği dışında ilişki kuramayan birey için, yapının korunması önemli bir gerekçe haline dönüşmemektedir. Kerpiç bir mescidin yerine modern bir caminin, ahşap bir iç sofalı evin yerine çok katlı bir apartmanın inşa edilmesi, bu algı noksanlığı dolayısıyla kitleyi rahatsız etmemektedir (Fotoğraf 13).

\footnotetext{
${ }^{27}$ Örneğin Ortaçağ Anadolu Türk Mimarisinde 'güçlü etkisi' kendini en çok taçkapılarda hissettirmiştir (Mülayim, 2010: 94). Fakat günümüzde, özellikle iç Anadolu bölgesinde inşa edilen pek çok modern kamu yapısının giriş kapılarının bir öykünmeye bağlı olarak taç kapı formunda yapılması, o yapılara bir güçlü imajı verememektedir.

${ }^{28}$ Mimari merkezli benzer bir tespit günümüze gelen en eski mimarlık kitabının yazarı olan Vitrivius tarafından 2000 yıl önce yapılmıştır. Vitrivius'a göre iyi bir mimarın mimarlık bilgisi dışında felsefe, geometri, astronomi ve müzik bilgisinin olması gerekmektedir. Bkz. Vitrivius, Mimarlık Üzerine On Kitap, (Çev. Suna Güven), Şefik Vanlı, Ankara, 2013, s. 7,8.

${ }^{29}$ II. Ulusal Mimarlık Akımı için bkz. Metin Sözen, Cumhuriyet Dönemi Türk Mimarlığı, İş Bankası, Ankara, 1984. Doğan Hasol, 20. Yüzyıl Türkiye Mimarlığı, Yem, İstanbul, 2017.
} 
Problem, İslam Dünyası açısından bir hezeyan boyutundayken; nispeten daha iyi durumda olan Hıristiyan dünyanın algısı da; beklenen seviyede değildir. Örneğin bugün pek çok batılı Hz. İsa'nın sembolü olarak kabul ettikleri haçın, aslında dikey ve yatay bir sembolizmi temsil ettiğini ve bu bakımdan yeryüzündeki yatay gelişime, gökyüzüne doğru ise dikey gelişime işaret ederek aslında evrensel bir insanı kâmil simgesi olduğundan habersizdir (Guenon, 2001: 23,24). Bu kadar derinlemesine bir analizin herkes tarafından yapılabilmesini beklemek haksızlık gibi görünebilir. Lakin Hıristiyanlığın en önemli simgesinin modern çağla beraber batı için dinî bir sembol olmanın ötesinde bir estetik imaja dönüşmüş olması da, yabana atılmayacak ölçüde yadırgatıcıdır (Fotoğraf 14). Buna rağmen batının özellikle kültürel mirası koruma bilinci açısından doğunun çok önünde bir algıya sahip olduğu kesindir. Zira pek çok Avrupa şehrinde tarihî dokunun büyük oranda korunduğunu ve katedrallerin hâlen şehir merkezlerinin en abidevi yapıları olduğunu görmek mümkündür (Fotoğraf 15-17).

Batının kültür varlıklarının bir değer olarak algılanıp kavranması ve korunması açısından İslam dünyasından daha önde olmasının nedenlerinin başında kuşkusuz eğitim müfredatı gelmektedir. Günümüzde Avrupa ülkelerinin tamamında görsel sanatlar, el sanatları, müzik, dans, medya sanatları ve mimari konulu dersler ilköğretim altı (ISCED 1) düzeyde zorunlu; ilköğretimin üst basamağında ise (ISCED 2), hemen hemen bütün Avrupa Birliği ülkelerinde zorunludur (Avrupa Komisyonu, 2009: 26) ${ }^{30}$. Şüphesiz kültür ve sanat içerikli derslerin erken yaşlarda alınmaya başlanması, özellikle bir koruma bilincinin oluşmasına ve bunun kültüre dönüşmesine olanak tanımaktadır.

Görüldüğü üzere gerek doğuda gerekse batıda, neredeyse Neolitik Dönem'den itibaren -ister mitler ister dinler aracılığıyla olsun- inanç, sanat vasıtasıyla kendi algısını yaratmak istemiş, bunu yaparken de, muhatabında kalıc bir etki bırakmak için dolaylı (simgesel) bir anlatım tarzını kullanmıştır. Bu algısal süreç, insan düşüncesinin ve muhayyilesinin bir ürünü olarak, kendi çağına kadarki tüm birikimleri içine alacak ve çağının dünya görüşünü yansıtacak şekilde oluşmuştur. Bugün ise maalesef özellikle İslam Dünyası, kendi çağının aklını salt ilahiyatın argümanlarıyla yakalamaya çalışmakta, kendi sanatını ve mimarisini ortaya koyamamakta ve çağın ürünü olan soyutlamaları yapamayarak geçmişin basit kopyalarıyla avunmak zorunda kalmaktadır. Sürecin en kötü tarafı ise; bu bilincin maalesef neyi kaybediyor olduğunu halen daha anlayamamış olmasıdır.

30 ilgili komisyon raporu için bkz. http://eacea.ec.europa.eu/EDUCATION/EURYDICE/documents/thematic_reports/113TR.pdf. 


\section{Kaynaklar}

Adler, A. (2002). Sosyal Duygunun Gelişiminde Bireysel Psikoloji, Çev. Halis Özgü, İstanbul.

Aydın, M. (2017). Sembolden İşaretsele Düşüncenin Dönüşümü, Sosyoloji Divanı, C:8, Konya, s. 31-41.

Barthes, R. (2016). Göstergebilimsel Serüven, Çev. Mehmet Rıfat ve Sema Rıfat, YKY, İstanbul.

Bayat, F. (2017). Mitolojiye Giriş, Ötüken, Ankara.

Burke, E. (2008). Yüce ve Güzel Kavramlarımızın Kaynağı Hakkında Felsefi Bir Soruşturma, Çev. M. Barış Gümüşbaş, Bilgesu, Ankara.

Bülbül, M. (2017). Imgesel Iletişim, Çizgi, Konya.

Burckhardt, T. (2009). İslam Sanatı Dil ve Anlam, Çev. Turan Koç, Klasik, İstanbul.

Burckhardt, T. (2017). Doğu'da ve Batı'da Kutsal Sanat, Çev. Tahir Uluç, İnsan, İstanbul.

Can, Ş. (2016). Klasik Yunan Mitolojisi, Ötüken, İstanbul.

Cündioğlu, D. (2012). Mimarlık ve Felsefe, Kapı, İstanbul.

Cündioğlu, D. (2007). Daireye Dair, Düşünce, İstanbul.

Çaycı, A. (2016). "İslam Mimarisinde Anlam Meselesi", Sosyoloji Divanı, Sayı: 7, s.189-202.

Çaycı, A. (2016). "Zaman ve Sanat Bağlamında Çark-ı Felek Motifi", Uluslararası İslam Medeniyetinde Zaman Sempozyumu Bildirileri, (8-11 Ekim 2015), C:2, Konya, s.299-305.

Çaycı, A. (2016). İslam Mimarisinde Anlam ve Sembol, Palet, Konya.

Demiriz, Y. (2001). İslam Sanatında Geometrik Süsleme, Yorum Sanat, İstanbul.

Demirli, E. (2014). "Tasavvufta Estetik Algısı Hakkında Bir Değerlendirme", VI. Dini Yayınlar Kongresi-Islam Sanat ve Estetik- Bildirileri, İstanbul, s.105-110.

Dündar, A. (2017). “Kubbetü's-Sahra”, Vakıf ve Toplum, Sayı: 5, Ankara, s. 54-59.

Eliade, M. (2004). Mistik Hint Erotizmi, Çev. Renan Akman, Kabalcı, İstanbul.

Eliade, M. (2014). Dinler Tarihine Giriş. Kabalcı, İstanbul.

Eliade, M. (2017). Kutsal ve Kutsal Dışı, Çev. Ali Berktay, Alfa, İstanbul.

Ersoy, N. (1990). Semboller ve Yorumlarla Görünenden Görünmeyene, Kam Ajans, İstanbul.

Eco, U. (2013). Efsanevi Yerlerin Tarihi, Doğan, İstanbul.

Eco, U. (2016). Ortaçağ Estetiğinde Sanat ve Güzellik, Can, İstanbul.

Freud, S. (1994). Psikanaliz Üzerine, Çev. Avni Öneş, İstanbul. 
Guenon, R. (2001). Yatay ve Dikey Boyutların Sembolizmi, Çev. Fevzi Topaçoğlu, İnsan, İstanbul.

Guenon, R. (2014). Alemin Hükümdarı, (Çev. İsmail Taşpınar), İnsan, İstanbul.

Guenon, R. (2014). Dante ve Orta Çağ'da Dini Sembolizm, Çev. İsmail Taşpınar, İnsan, İstanbul.

Grimal, P. (2012). Mitoloji Sözlüğü, Çev.Sevgi Tamgüç, Kabalcı, İstanbul.

Grabar, O. (2010). İslam Sanatı'nın Oluşumu, Çev. Nuran Yavuz, Kanat, İstanbul.

Hançerlioğlu, 0. (1985). Felsefe Ansiklopedisi, Remzi, İstanbul.

Homeros, (1999). ilyada, Çev. A. Erat ve A. Kadir, Can, İstanbul.

İbn Arabi, (2015). Harflerin Esrarı, Çev. Ekrem Demirli, Litera, İstanbul.

Jung, C. G. (1997). Analitik Psikoloji, Çev. Ender Gürol, Payel, İstanbul.

Jung, C. G. (2016). Insan ve Sembolleri, Çev. H. Mukaddes illgün, Kabalcı, İstanbul.

Kaya, M. (2014). Hz Ali'den 111 Hatıra, Erkam, İstanbul.

Kandinsky, W. (2015). Sanatta Ruhsallık Üzerine, Çev. Gülin Ekinci, Altıkırkbeş, İstanbul.

Lekesiz, Ö. (2016). Sevgili'nin Evi, Şule, İstanbul.

Lewcock, R. (1996). "Architects, Craftsmen and Builders: Materials and Techniques", Architecture of the Islamic World, (Edit. G. Michell), London, s. 112-143.

Leppert, R. (2009). Sanatta Anlamın Görüntüsü, Çev. İsmail Türkmen, Ayrıntı, İstanbul.

Mevlana Celaleddin, (1994). Fîhi Mâfih, Çev. A. Avni Konuk, Yay. Haz. S. Eraydın, İz, İstanbul.

Mülayim, S. (2010). İslam Sanatı, İSAM, İstanbul.

Necmeddin-i Daye, (2013). Mirsadü'l-libad, Çev. Halil Baltacı, IFAV, İstanbul.

Otto, R. (2014). Kutsal'a Dair, Çev. Sevil Ghaffari, Altıkırkbeş, İstanbul.

Ögel, B. (1998). Türk Mitolojisi I-II, TTK, Ankara.

Rosenberg, D. (2000). Dünya Mitolojisi, İmge, İstanbul.

Roth, M.L. (2002). Mimarlığın Öyküsü, Kabalcı, İstanbul.

Sâî Mustafa Çelebi, (2003). Tezkiretü'I-Bünyan ve Tezkiretü'l-Ebniye, Yay. Hz. Hayati Develi, KOÇ Kültür Sanat Tanıtım, İstanbul.

Saydam, M. B. (2013). Deli Dumrul'un Bilinci, Metis, İstanbul.

Susuz, M. (2016). "Tüketim Kültürünün Sanata Yansıması”, Inönü Üniversitesi Sanat ve Tasarım Dergisi, S:6, s.200-211. 
Tatar, B. (2016). İslam Düşüncesine Giriş, DEM, İstanbul.

Tuğlacı, P. (1985). Osmanlı Şehirleri, Milliyet, İstanbul.

Tunalı, i. (1989). Grek Estetiği, Remzi, İstanbul.

Tunalı, i. (2004). Estetik, Remzi, İstanbul.

Vitrivius, (2013). Mimarık Üzerine On Kitap, Çev. Suna Güven, Şevik Vanlı Mimarlık Vakfı, Ankara.

Werner, M. (2012). Mimarlık Atlası, Yem, İstanbul.

Yanıklar, C. (2010). "Tüketim Kültürü, Kapitalizm ve İnsan İhtiyaçları Arasındaki iliş̧ki Üzerine Bir Tartışma”, Cumhuriyet Üniversitesi Sosyal Bilimler Dergisi, C:34, S:1, s.25-32.

Yetkin, S. K. (1959). İslam Mimarisi. AÜ Illahiyat Fakültesi, Ankara.

Yıldırım, N. (2012). Iran Mitolojisi, Pinhan, İstanbul. 
Muzaffer YILMAZ

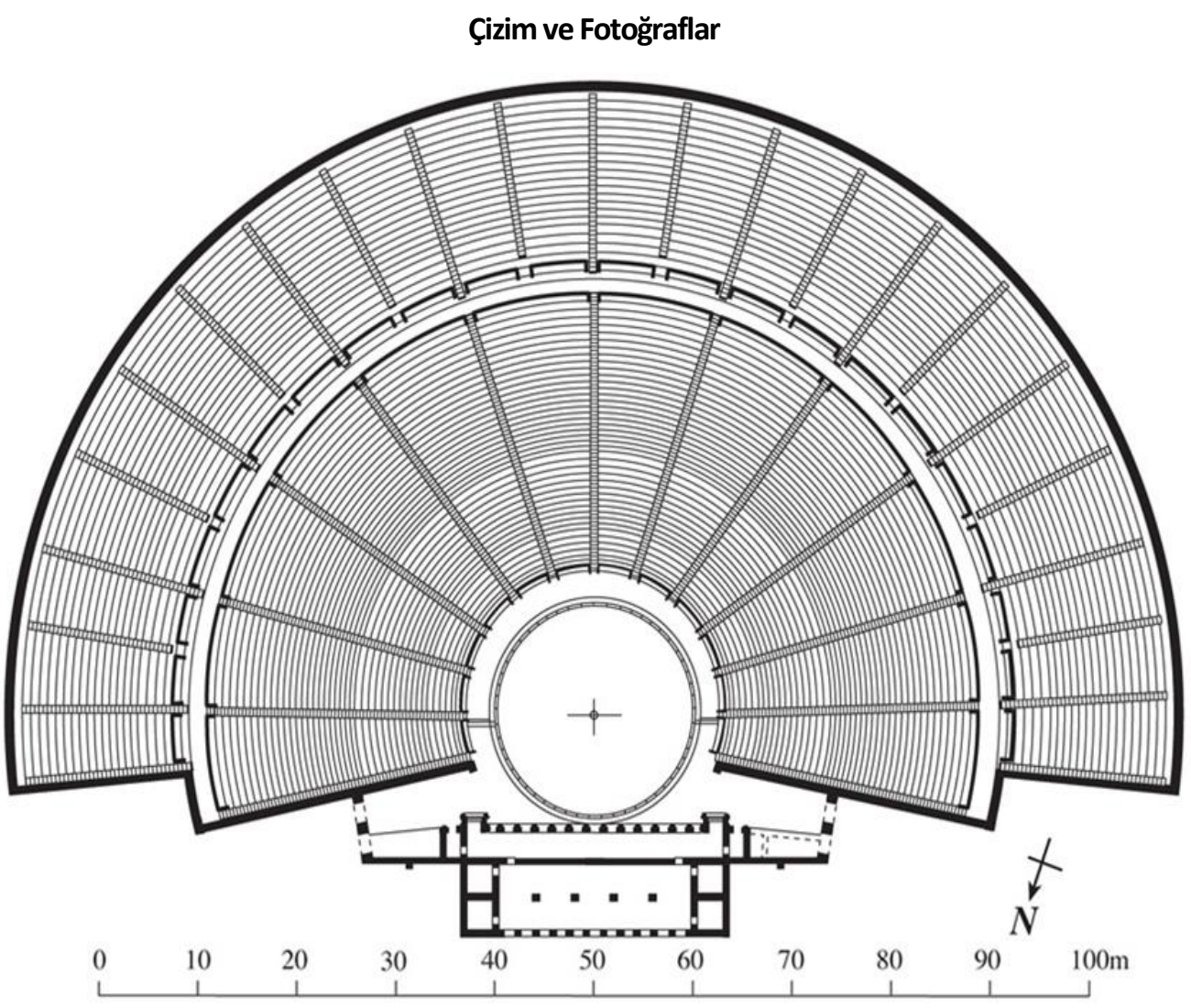

Çizim 1. Epidaurus Tiyatrosu Planı, MÖ 300-450 (Ancient Theatre Archive) 


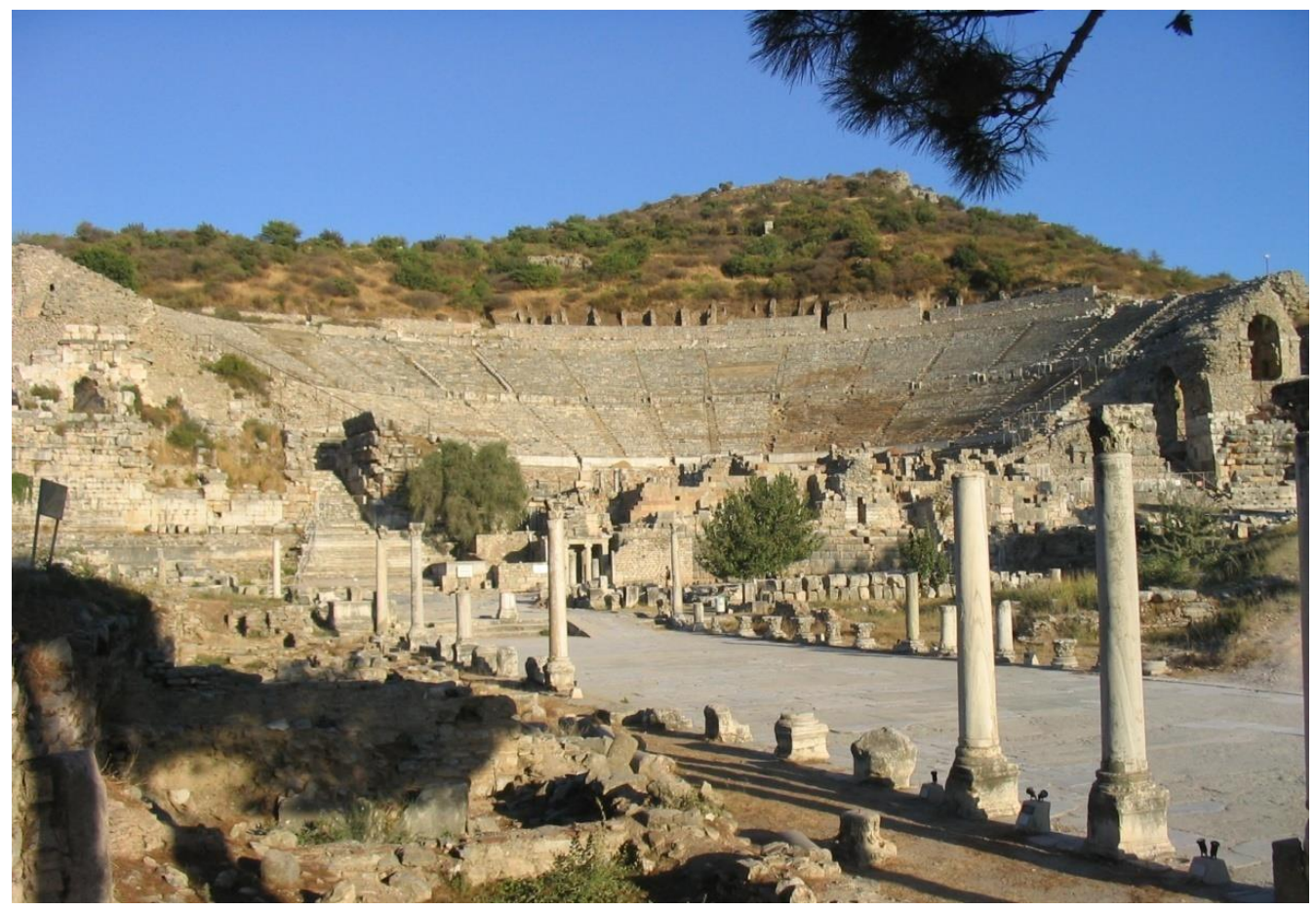

Fotoğraf 1. Efes Tiyatrosu 
Muzaffer YILMAZ

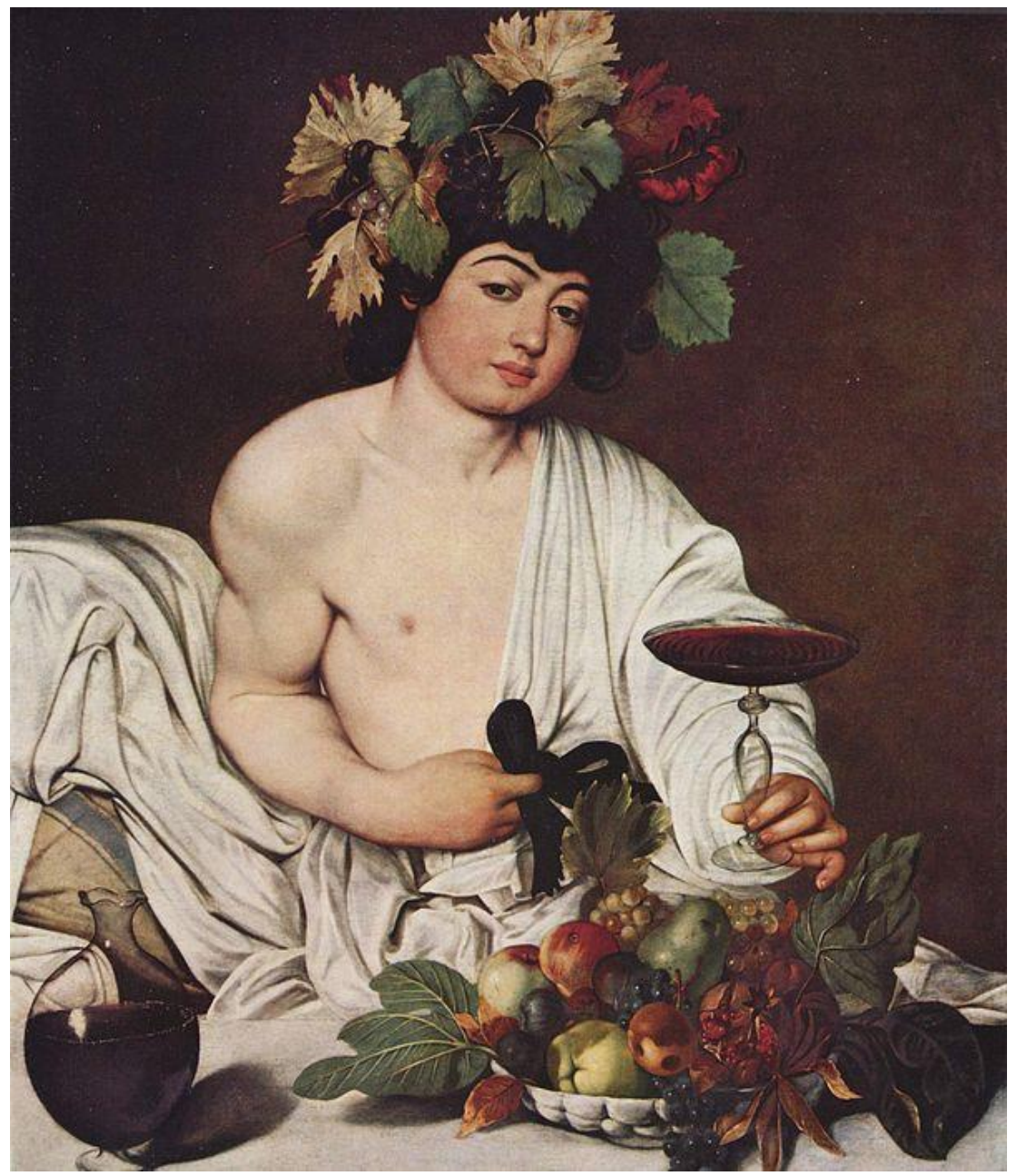

Fotoğraf 2. Baküs Tablosu 17. Yüzyıl, (Caravaggio) 


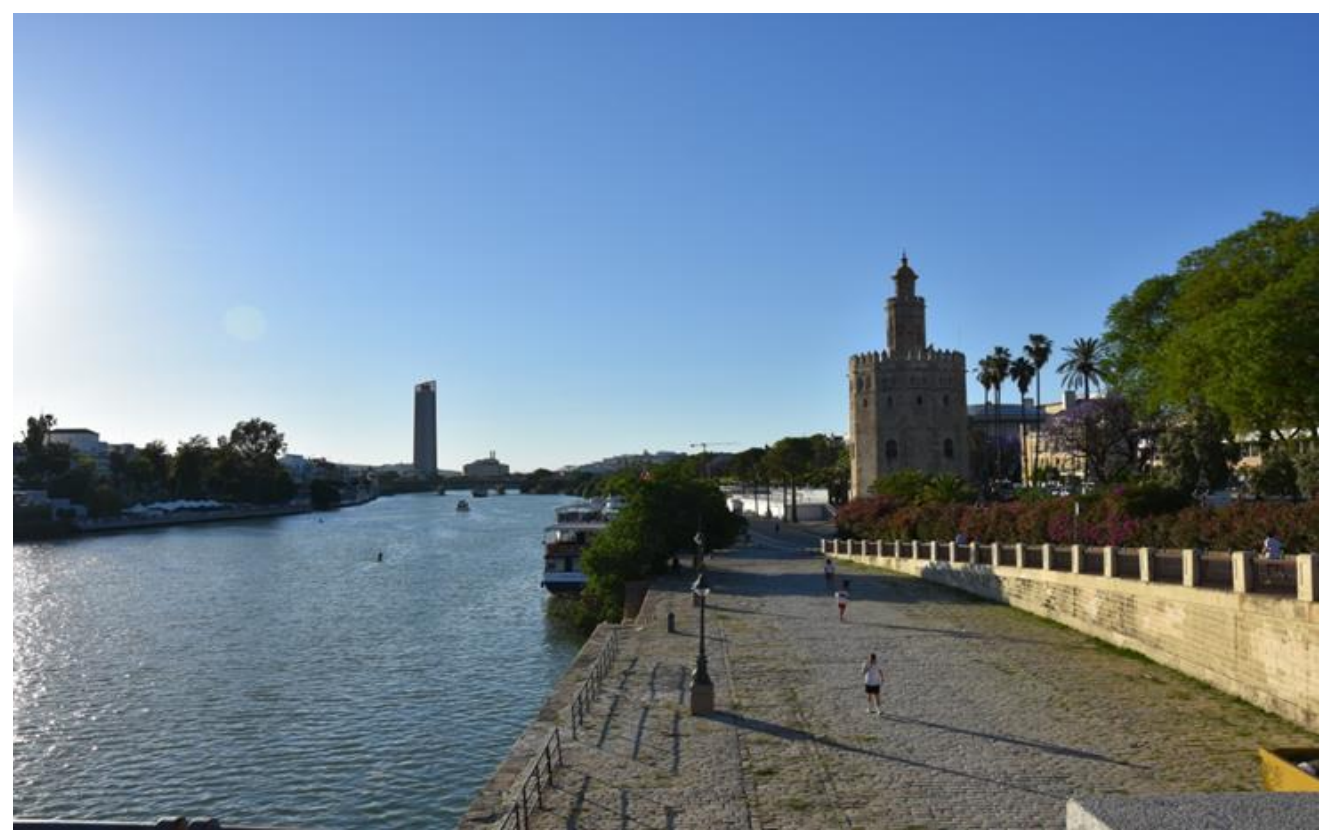

Fotoğraf 3. Sevilla Şehri ve Quadelkebir (Vadi-elkebir) Nehri

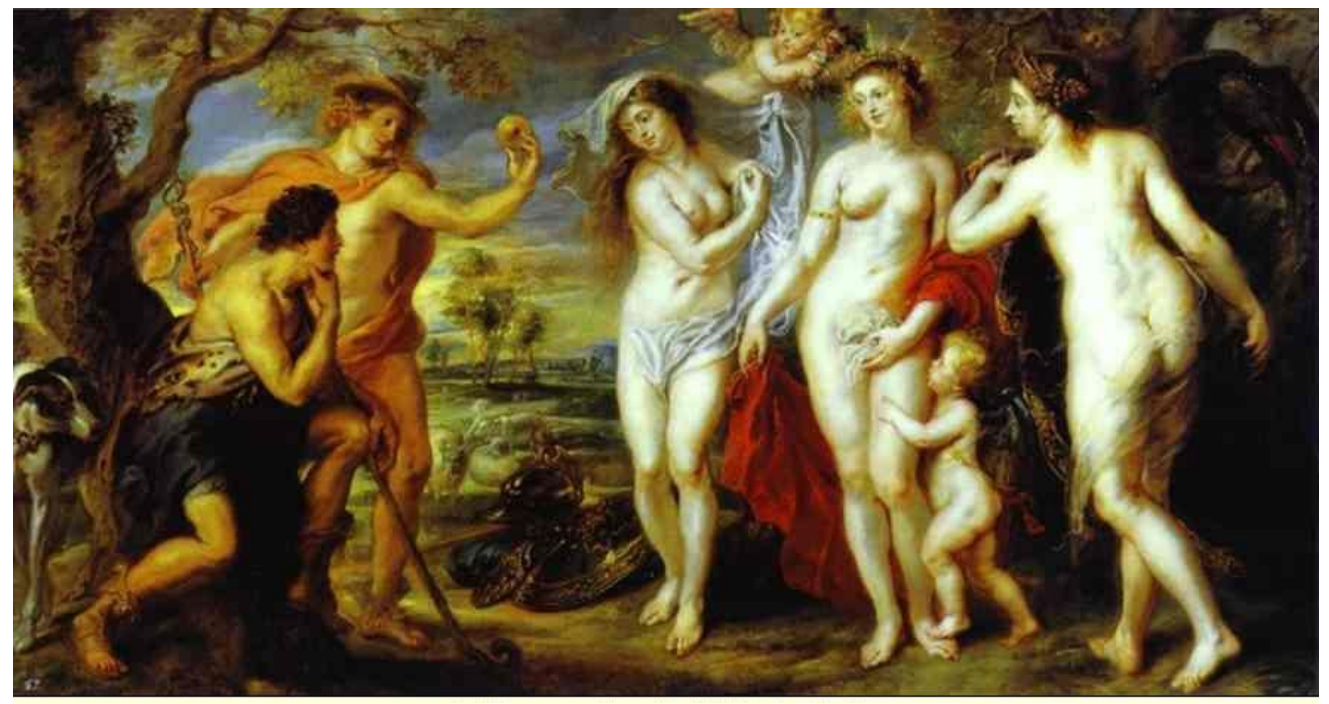

Fotoğraf 4. Paris'in Seçimi Tablosu 1639 (P. Peter Rubens) 


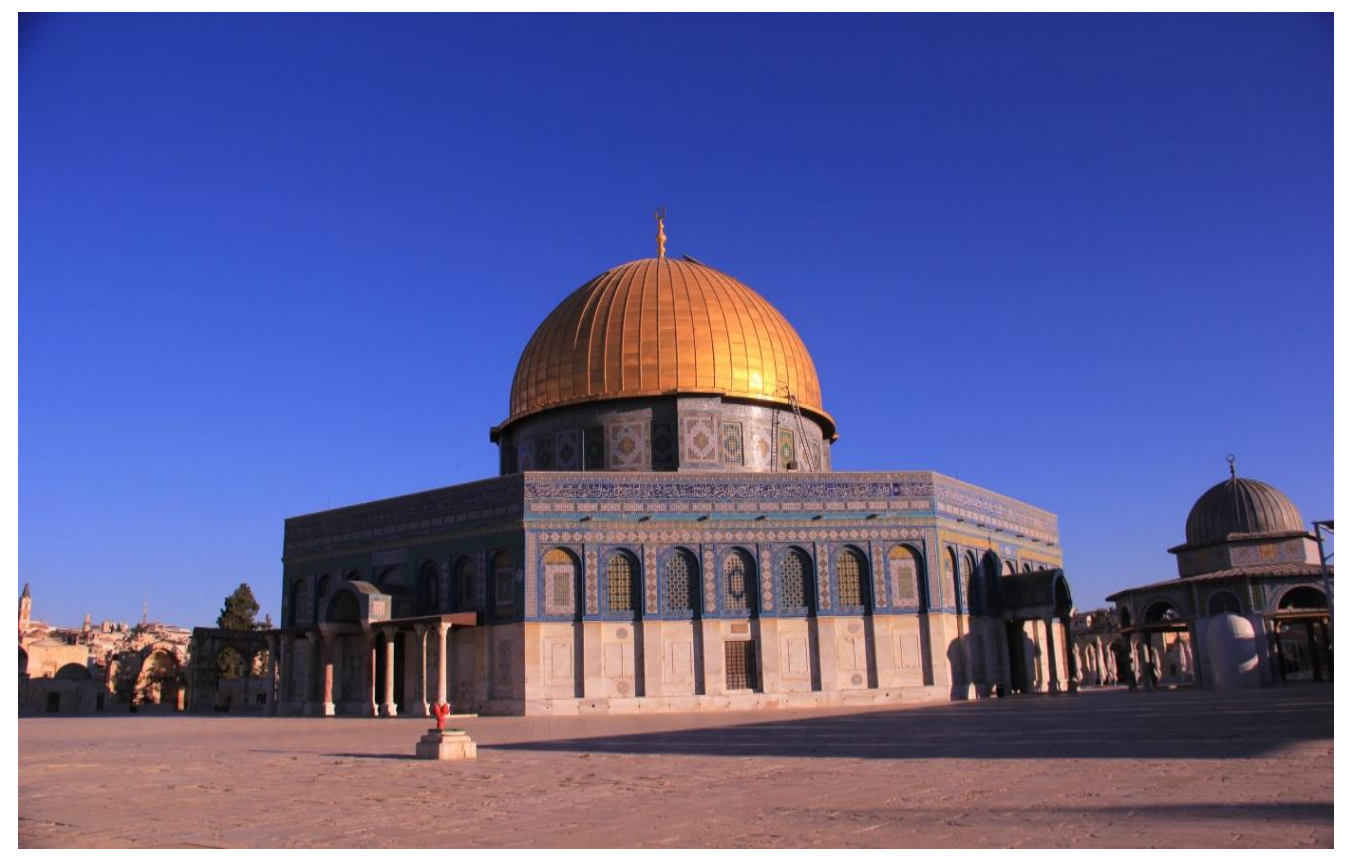

Fotoğraf 5. Kubbetü's Sahra (Zekeriya Şimşir)

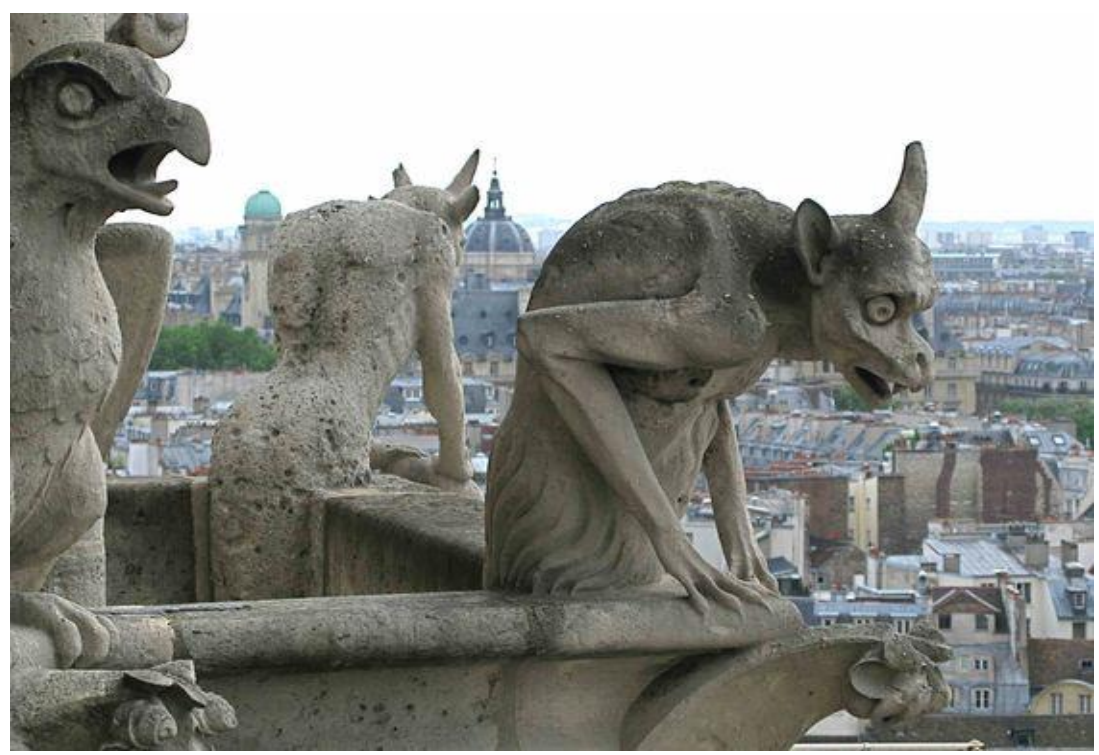

Fotoğraf 6. Notre Dame Katedrali Detay (Michael May) 
Eskişehir Osmangazi Üniversitesi Sosyal Bilimler Dergisi

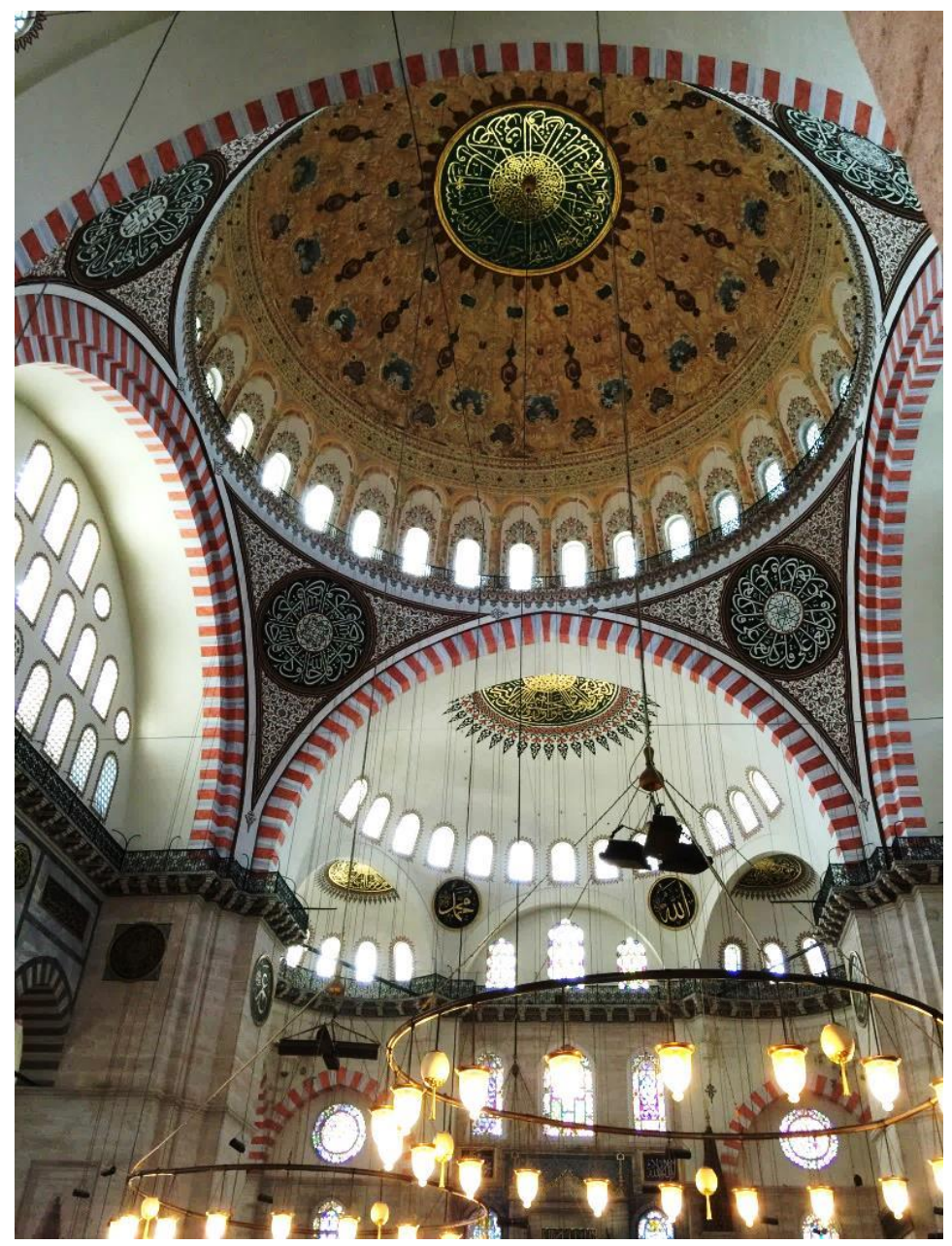

Fotoğraf 7. İstanbul Süleymaniye Camii 


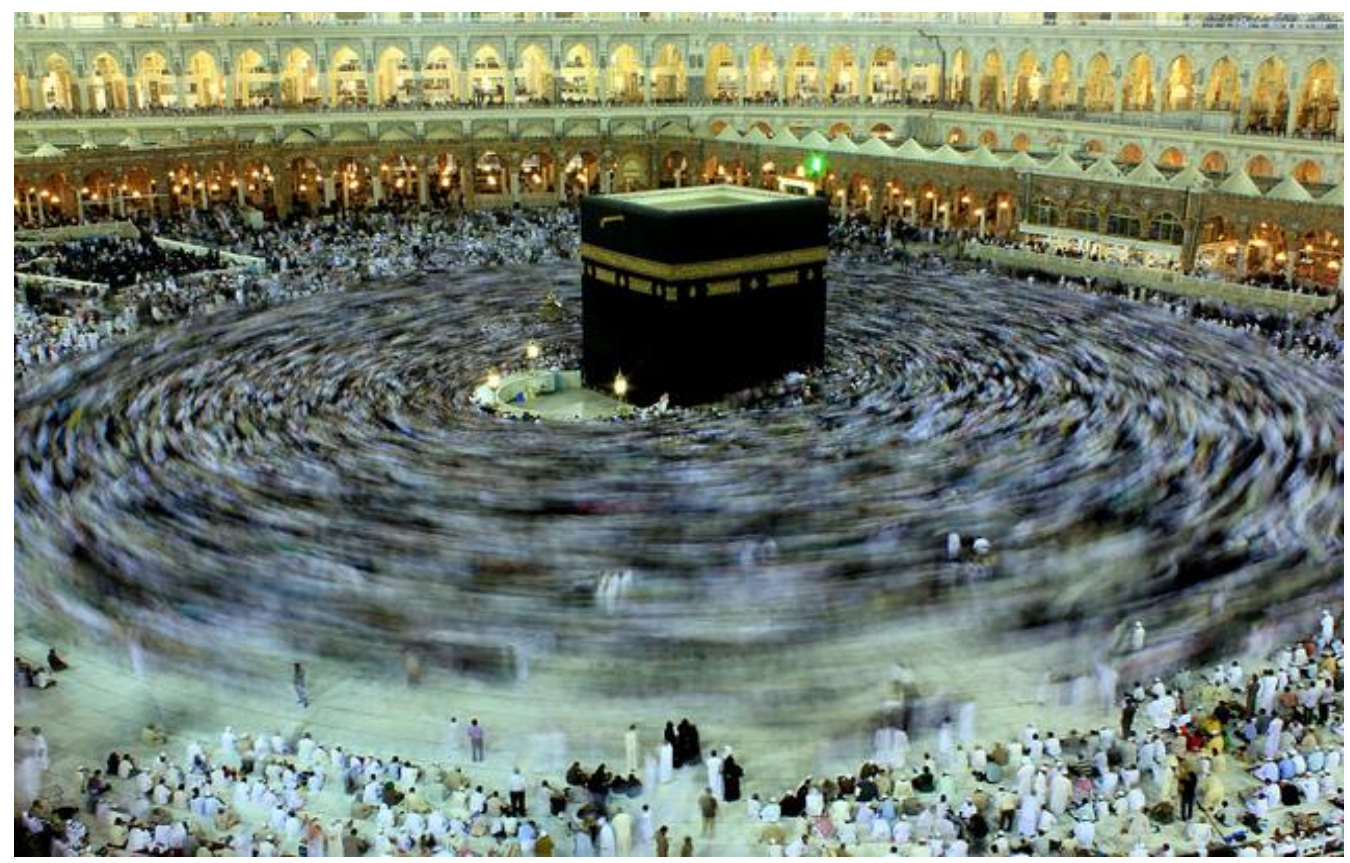

Fotoğraf 8. Kâbe (insaninyolu.com)

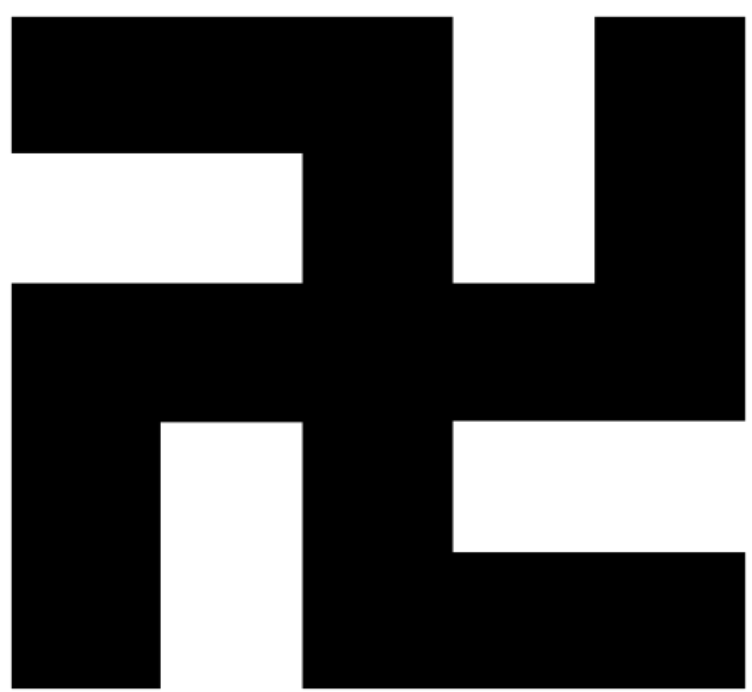

Fotoğraf 9. Svastika Motifi 


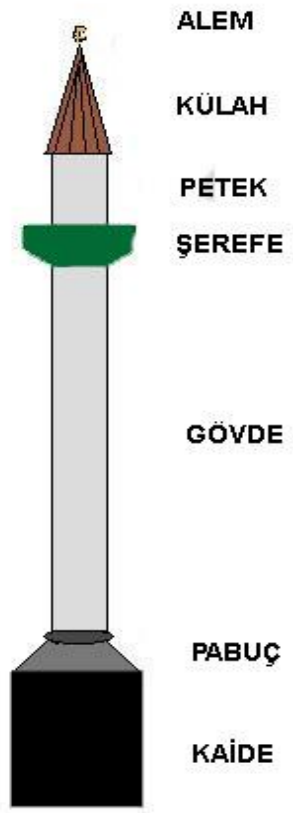

Fotoğraf 10. Minare ve Bölümleri

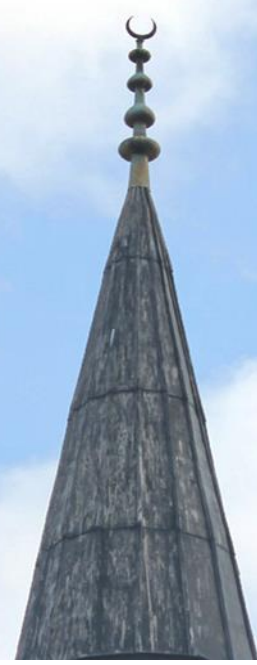

Fotoğraf 11. Fatih Piri Mehmet Paşa Camii Minare Külahı ve Alemi 


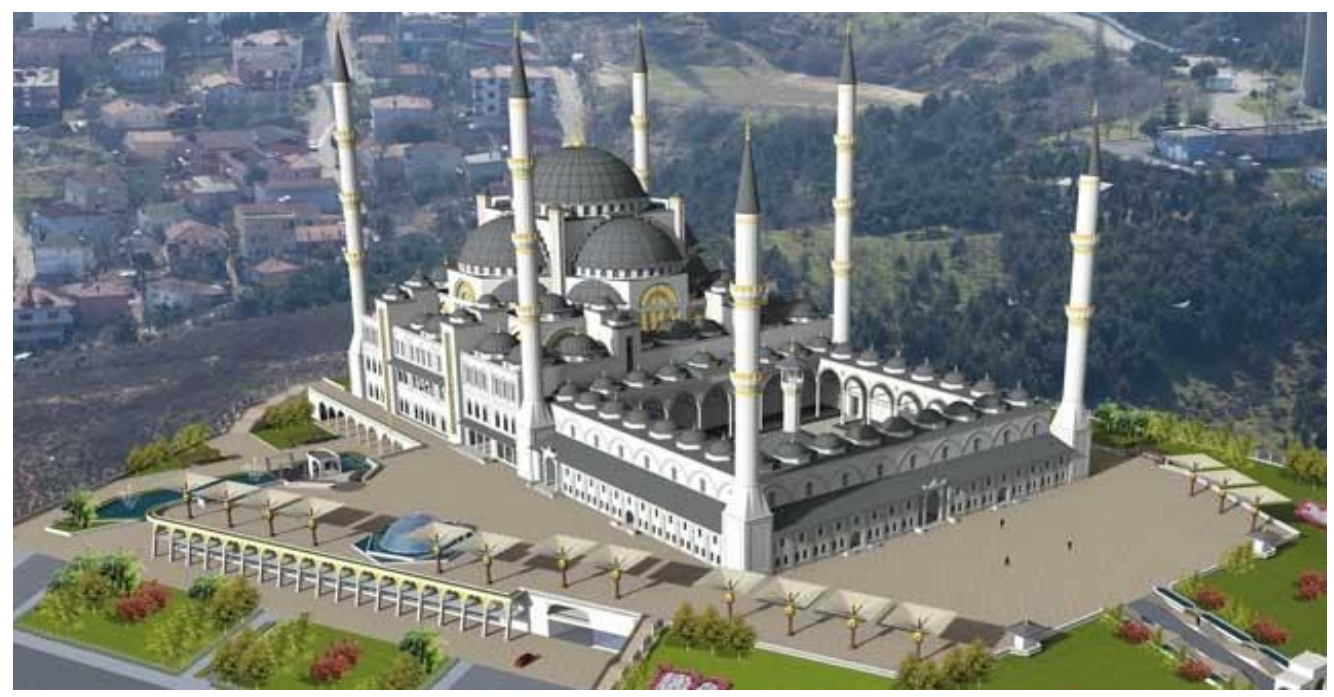

Fotoğraf 12. Çamlıca Camii 3D Maketi (TRT Haber)

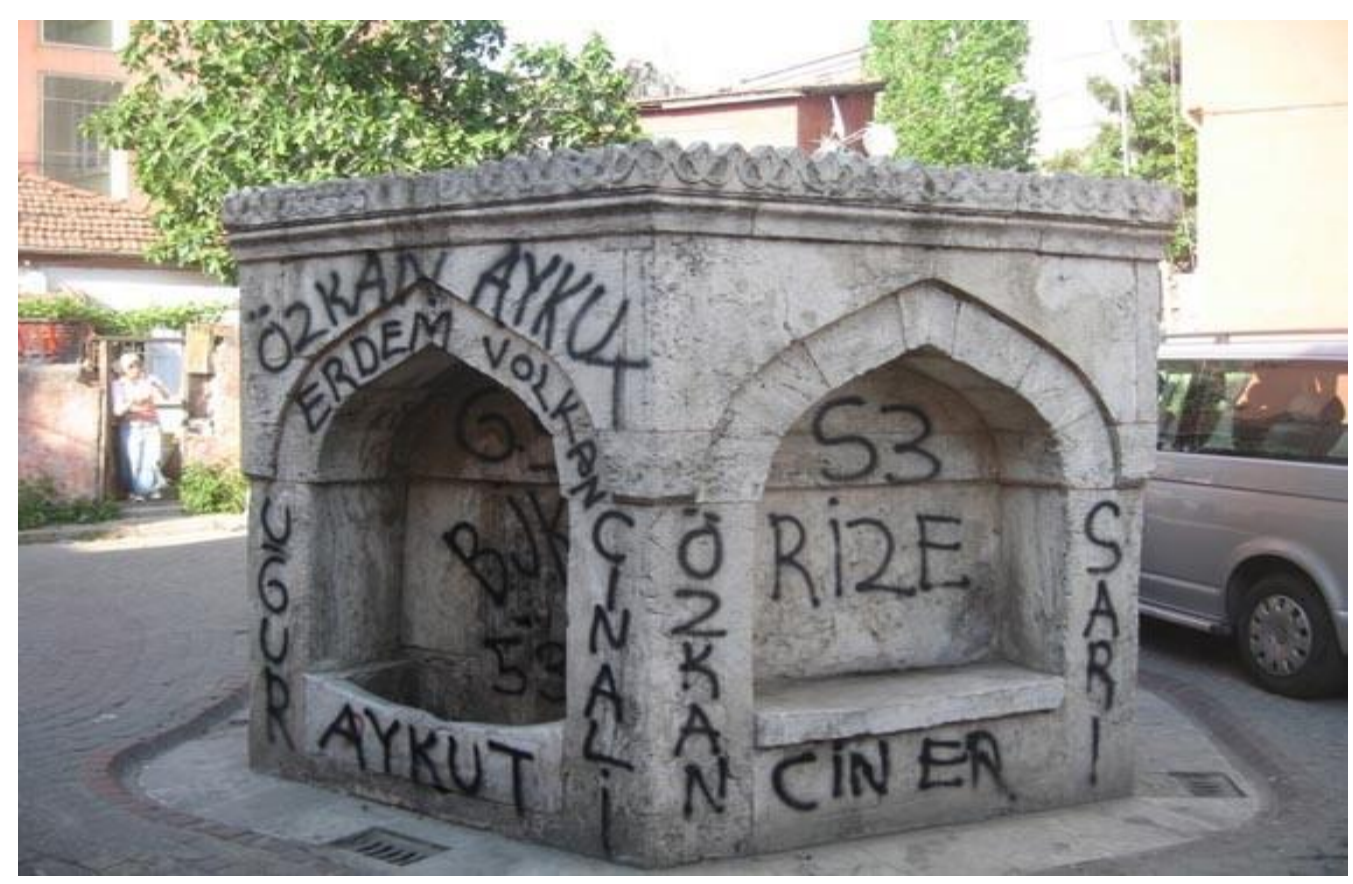

Fotoğraf 13. Ayvansaray Mimar Mustafa Ağa Çeşmesi (Fatih Köse) 


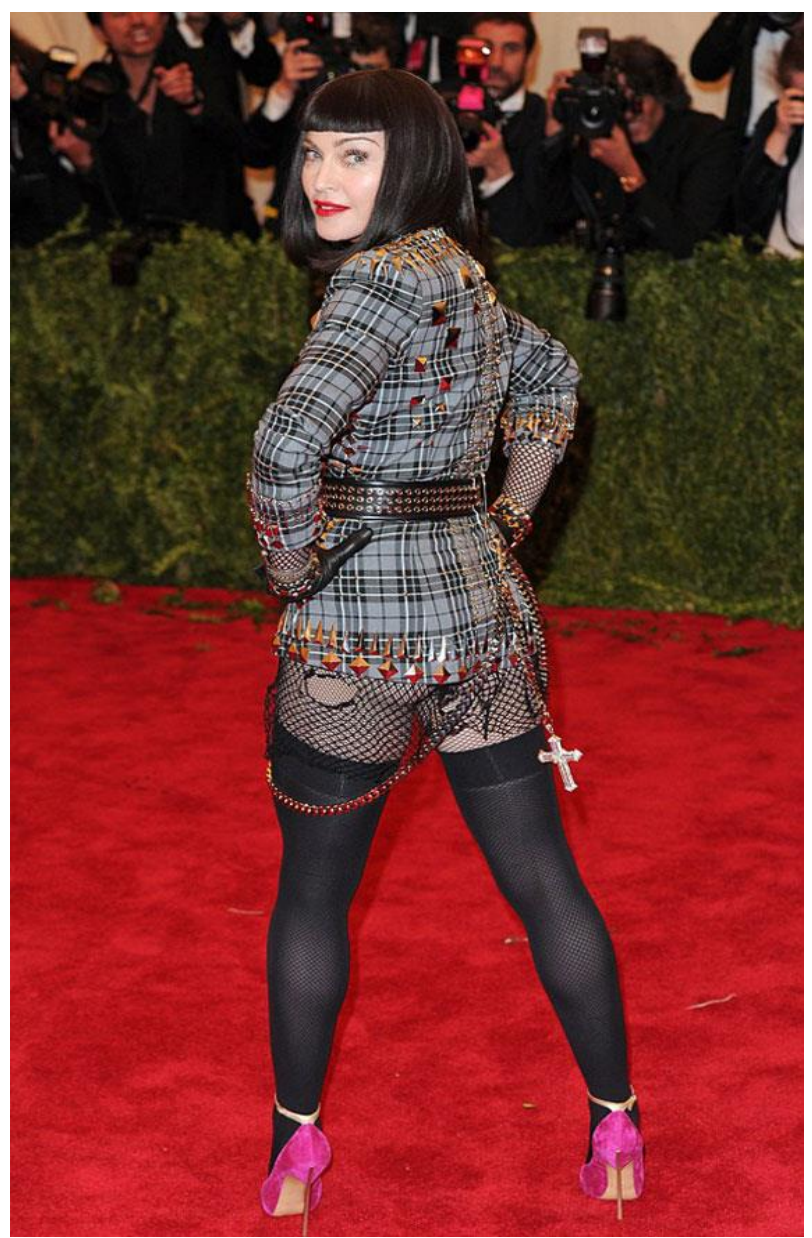

Fotoğraf 14. Haç Formlu Aksesuarı İle Madonna (celebs-place.com)

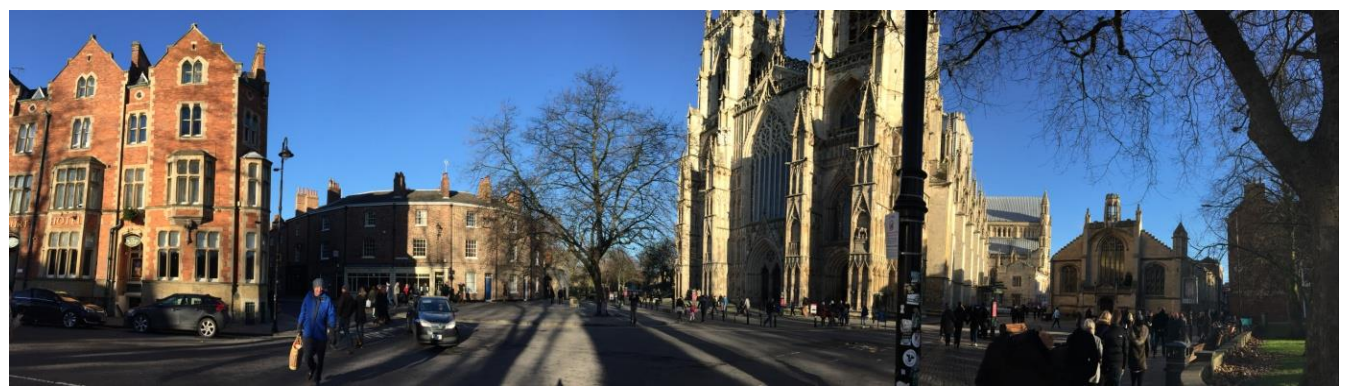

Fotoğraf 15. York (İngiltere) 


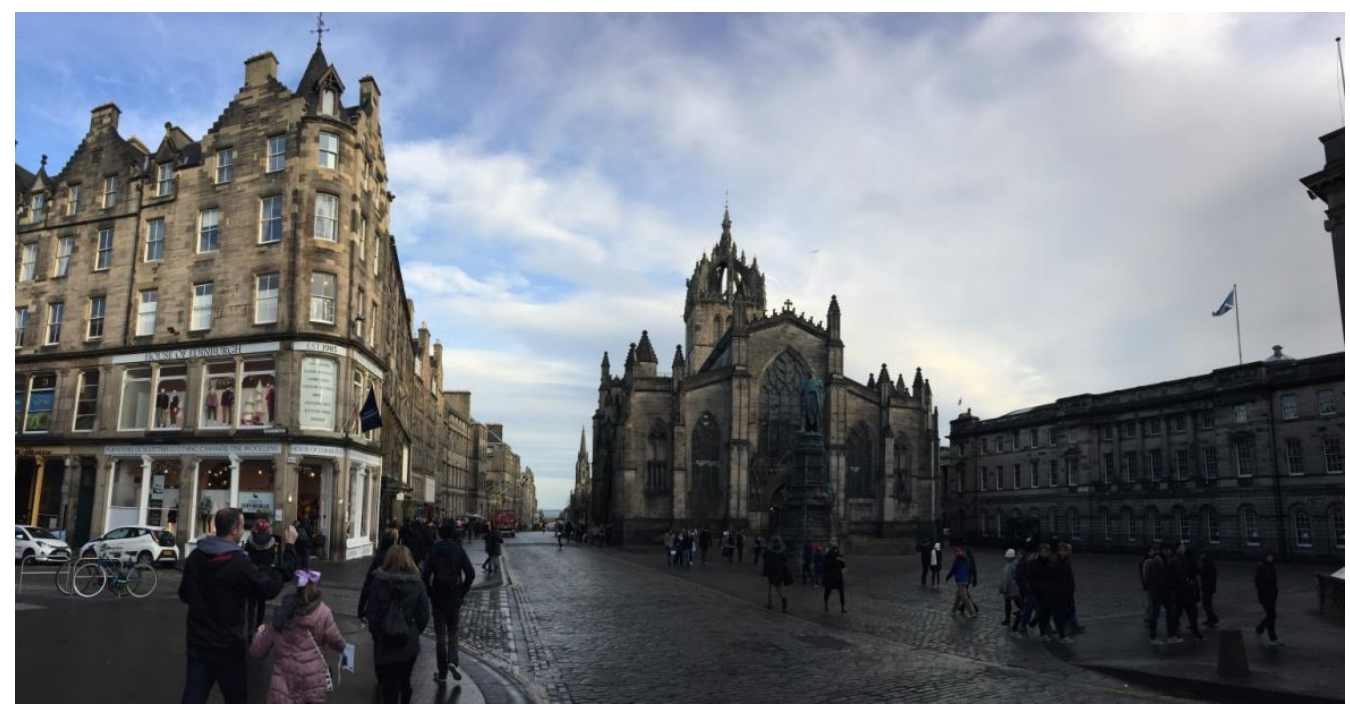

Fotoğraf 16. Edinburgh (İskoçya)

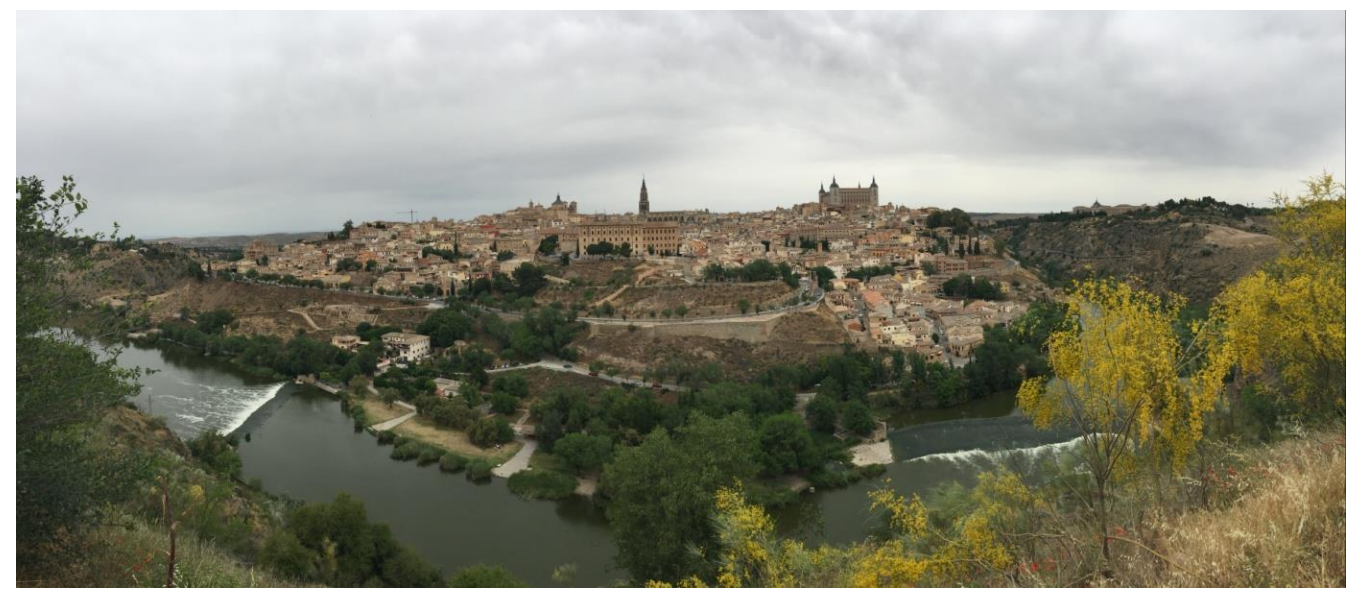

Fotoğraf 17. Toledo (İspanya) 